\title{
Substance use and common child mental health problems: examining longitudinal associations in a British sample
}

\author{
Anna Goodman ${ }^{1}$
}

1 London School of Hygiene \& Tropical Medicine, London, UK

Corresponding author: Anna Goodman, London School of Hygiene \& Tropical Medicine, Keppel Street, London, WC1E 7HT, UK (anna.goodman@1shtm.ac.uk).

Note: this is a personal version, created by Anna Goodman, of the text of the accepted journal article. It reflects all changes made in the peer review process, but does not incorporate any minor modifications made at the proof stage. The complete citation for the final journal article is:

- Goodman, A; (2010) Substance use and common child mental health problems: examining longitudinal associations in a British sample. Addiction. Addiction, 105 (8) pp. 1484-1496

- DOI: 10.1111/j.1360-0443.2010.02981.x

Copyright $(\subseteq$ and Moral Rights for this paper are retained by the individual authors and/or other copyright owners 


\section{$\underline{\text { Abstract }}$}

Aim: To examine the longitudinal associations in both directions between mental health and substance use in adolescence.

Participants and design: 3607 youth aged 11 to 16 years at baseline and followed for three years.

Setting: Britain (nationally-representative sample).

Measurements: Externalizing and internalizing mental health problems were measured using brief questionnaires (parent-reported Strengths and Difficulties Questionnaire) and diagnostic interviews, including clinician-rated diagnoses of mental disorder. Substance use was measured by youth self-report, and included regular smoking, frequent alcohol consumption, regular cannabis use and ever taking other illicit drugs.

Findings: Externalizing (specifically behavioral) problems at baseline independently predicted all forms of substance use, with a particularly strong effect on smoking. In all cases this association showed a dose-response relationship. By contrast, although internalizing problems had a strong univariable association with smoking, this disappeared after adjusting for comorbid externalizing problems. There was little or no evidence that baseline substance use predicted mental health at follow-up.

Conclusion: Externalizing problems predict adolescent substance use, and adjusting for comorbid externalizing problems is vital when investigating the effects of internalizing problems. A dose-response effect of externalizing problems is seen across the full range. Programs seeking to prevent adolescent substance use by reducing externalizing problems may therefore wish to consider population-wide interventions rather than only targeting individuals at the negative extreme.

Three citable statements:

- In British youth, externalizing problems in early adolescence show a dose-response association with regular smoking, high alcohol consumption, regular cannabis use and lifetime illicit drug use in late adolescence.

- Internalizing problems in early adolescence do not predict later substance use after adjustment for comorbid externalizing problems; such adjustment is therefore vital in order to avoid misleading findings.

- Substance use in early adolescence has little or no independent predictive effect on mental health in late adolescence. 


\section{Introduction}

It is well-established that externalizing problems and disorders in early or middle childhood predict substance use, abuse and dependence in adolescence and young adulthood. With very few exceptions (1), this has been shown for tobacco (2-8), cannabis $(2,6,9-14)$ and other illicit drug use $(6,15)$. This has also been shown for alcohol $(6,9,11,15-17)$, although the effect is often weaker and not always observed for alcohol use (as opposed to abuse) $(18,19)$. A growing body of evidence indicates that these associations are mainly driven by behavioral problems - hyperactivity, the other broad subgroup of externalizing problem, has little or no independent effect $(6,10,16,20)$.

For internalizing problems (depression and anxiety) the evidence is less clear. Interpreting many studies is complicated by a failure to adjust for possible comorbidity with externalizing problems (21-24). Among studies which do control for comorbidity, some report independent effects upon substance use or dependence $(1,10,25)$ while others do not or report only weak or inconsistent effects $(7,12,13,26,27)$.

As for the effect of substance use upon future mental health, there is relatively consistent evidence that smoking cigarettes or cannabis during adolescence predicts anxiety (26, 28-32), depression $(6,28,33-36)$ and perhaps behavioral problems $(29,37)$ in early adult life. Relatively few studies, however, examine mental health outcomes within the teenage years. These produce more mixed results $(1,7,37-39)$, including several negative or inconsistent findings $(7,37,38)$.

One complication in interpreting these findings is the focus of many studies on just one form of substance use. Given the substantial co-occurrence of substance use in young people (4042), this complicates attempts to determine the specificity of observed relationships or compare magnitude of different effects. In addition, most previous studies use only binary measures of disorder (e.g. 7, 15, 17) or 'high' questionnaire scores (e.g. 38). Far fewer look for evidence of a dose-response relationship, and while some suggest such effects $(6,43)$ others do not (10). Thus even for the well-established effect of behavioral problems upon future substance use, it is unclear how far this extends across the full range of oppositional, aggressive or antisocial behaviors in childhood.

In this paper I address these gaps in the evidence using two surveys of British 11 to 16-year olds who were then followed for three years. Specifically, I examine: 1) How far externalizing and internalizing problems at baseline predict substance use (tobacco, alcohol, cannabis and other illicit drugs) at follow-up; 2) How far any observed associations show a dose response relationship; and 3) How far substance use at baseline predicts mental health at follow-up. Cross-sectional analyses of the association between substance use and mental health have previously been published using the baseline data for youth aged 13-15 in the first of the two surveys (44). This is the first time, however, that such analyses have drawn on both surveys or made use of the follow-up data. 


\section{$\underline{\text { Methods }}$}

\section{$\underline{\text { Sample }}$}

The British Child and Adolescent Mental Health Surveys (B-CAMHS) of 1999 and 2004 were two nationally-representative surveys in England, Scotland and Wales. Children and adolescents were sampled at ages 5-15 in B-CAMHS99 and 5-16 in B-CAMHS04; otherwise the two studies used near-identical methods for sampling and data collection $(45,46)$.

The principal caregivers ('parents') of selected youth were approached for interview. With parental permission, a teacher and youth aged 11 or over were also approached. Between the two B-CAMHS surveys, 26_545 youth were selected and 18_415 (69.4\%) participated. This included 8577 youth aged 11 to 16, and therefore old enough to be interviewed about their substance use.

Both B-CAMHS surveys included a three-year follow-up. B-CAMHS99 oversampled participants with disorders at baseline (47) while B-CAMHS04 attempted to follow up all participants (48). In total 5835 youth aged 11 to 16 at baseline were selected for follow-up, and $3739(64.0 \%)$ participated. Of these, 3607 youth (1124 from B-CAMHS99, 2483 from B-CAMHS04) provided substance use data at baseline and/or follow-up, and these represent the study population for this paper. Their mean age was 13.2 years at baseline (16.2 years at follow-up) and $51.5 \%$ were male (12.9 years at baseline, $51.0 \%$ male in B-CAMHS99; 13.3 years at baseline $51.7 \%$ male in B-CAMHS04).

\section{$\underline{\text { Measures }}$}

\section{Mental health}

Parent SDQ: All parents completed the Strengths and Difficulties Questionnaire (SDQ: 49, 50). The 20 items of the SDQ's 'total difficulty score' provide a dimensional measure of common child mental health problems (51). The total difficulty score can also be separated into an 'internalizing' subscale made up of the 10 questions on emotional and peer problems (range 0-20), and an 'externalizing' subscale made up of the 10 questions on behavioral and hyperactivity problems (range 0-20). As the SDQ has only been validated for youth up to age 16 , I conduct sensitivity analyses excluding those aged 17 or more at follow-up.

Probability bands from the parent DAWBA: All parents were administered the Development and Well-being Assessment (DAWBA: 52, 53). This is a detailed psychiatric interview administered by lay interviewers, and including both fully-structured sections and open-ended descriptions of problems. Computer algorithms can use responses to the fullystructured sections to assign 'DAWBA bands', these being probability bands with up to 6 Levels which estimate the child's probability of having a particular type of disorder. This paper uses the three DAWBA bands for any internalizing disorder, any behavioral disorder and any hyperactivity disorder. I use the four-Level probability bandings: Level 0/1 (corresponding to $0.5 \%$ or below); Level 2 (around 3\%); Level 3 (around 15\%); and Level $4 / 5$ (50\% or above).

Clinician-rated diagnoses: DAWBAs were also completed by teachers and youth participating in B-CAMHS. Experienced child psychiatrists then used the fully-structured and open-ended information from all three informants to decide whether each child had a 
mental disorder. Diagnoses were assigned according to the Diagnostic and Statistical Manual of Mental Disorders, 4th edition (DSM-IV: 54); full details of all diagnoses covered by the DAWBA are provided in the Supporting Information. These diagnoses have been shown to have good reliability and validity $(52,53)$, including in predicting future service use or other adverse outcomes $(47,48)$.

\section{Substance use}

Participating youth were asked by laptop about their substance use. I used their responses to create four outcome variables:

- Regular smoker, defined as currently smoking one or more cigarettes per week, following the standard definition of the UK Office for National Statistics (55). This question did not give a time frame, instead asking about 'usual' behaviour. When adjusting for baseline smoking, I used four categories: Never smoked; ex-smoker; occasional smoker $(<1$ cigarette per week), and regular smoker $(\geq 1$ cigarettes per week).

- Frequent alcohol consumption, defined as being in the top 5-10\% for any given age in a question on current drinking frequency. This corresponded to drinking at least once a month at ages 11-12; once a fortnight at age 13; once a week at age 14; twice a week at ages 15-16; and daily at ages 17-19. This question did not give a time frame, instead asking about 'usual' behaviour.

- Regular use of cannabis, defined as at least once a month during the past year. When adjusting for baseline cannabis use, I used three categories: Never smoked cannabis in the last year; used cannabis less than once a month; and regular cannabis user.

- Other illicit drug use, defined as ever using solvents; ecstasy; amphetamines; LSD; tranquilisers; cocaine or heroin.

\section{$\underline{\text { Potential confounders }}$}

All multivariable analyses adjust for the youth's gender; age at baseline (11-12 years, 13-14 or 15-16); survey year (B-CAMHS99 vs. B-CAMHS04) and country (England, Scotland or Wales). They also adjust for six other parent-reported youth or family characteristics, measured at baseline. These are: youth's ethnic group (White, Black, Indian, Pakistani/Bangladeshi, or Other); youth's general health (Very bad, bad, fair, good, very good); parent's mental health, measured by the 12-item general health questionnaire (GHQ12: 56) and administered by laptop; family type (two-parent, lone parent, or stepfamily); responding parent's highest educational level (No qualifications, GCSEs, A-level/diploma, or degree); and housing tenure (owner occupier or renting).

\section{$\underline{\text { Statistical analyses }}$}

Substance use data was missing at baseline or follow-up for 686 youth (19.0\%); parent SDQ data was missing for 53 youth (1.5\%); and family confounder data was missing for 16 youth $(0.4 \%)$. I used multiple imputation to impute missing values under an assumption of missing at random (57), using the MICE command in Stata10.1 (58, 59). I used five imputations, including in the imputation model all explanatory and outcome variables plus the interactions with age and gender described below.

Multivariable models used logistic regression for substance use and mental disorder outcomes; ordered logistic regression for the four-level DAWBA bands; and linear regression 
for the continuous SDQ scales. Ordered logistic regression assumes that the effect of an explanatory variable is the same wherever one 'cuts' the outcome (e.g. the odds ratio for levels 2-4 vs. level 1 is the same as for levels 3-4 vs. levels 1-2). When likelihood ratio tests provided evidence $(\mathrm{p}<0.05)$ that this proportional odds assumption was violated, I instead present separate odds ratios for each change in level.

When modelling explanatory variables, I entered the SDQ subscales and DAWBA bands as linear terms in order to facilitate comparisons across models. Alternative models treating these as categorical variables yielded very similar substantive findings and did not suggest threshold or U-shaped relationships. Potential confounders were entered as unordered categorical variables, except for youth's general health and parent's mental health which were entered as linear terms. All analyses adjust for the oversampling of youth with disorder in B-CAMHS99.

To maintain a stable study population across analyses, I combined children with a disorder at baseline (persistent cases) and children without (incident cases). I conducted sensitivity analyses stratifying by disorder presence/absence, to examine possible differences between the predictors of disorder persistence and disorder incidence.

My focus in these analyses is upon the effect of mental health on substance use and substance use on mental health. For all these associations, I tested for interactions between 1) gender and 2) age in the fully-adjusted models. As this involved substantial multiple testing, I only report interactions significant at $\mathrm{p}<0.01$.

\section{$\underline{\text { Results }}$}

Table 1 describes the characteristics at baseline and follow-up of the 3607 youth in the study population. Compared to all 11 to 16 year olds in the B-CAMHS baseline surveys, there was strong evidence that this study population contained fewer youth aged 15 or 16, fewer youth from minority ethnic groups, and fewer youth with high externalizing SDQ scores. There was also weak evidence that youth who smoked regularly were underrepresented; for details, see the Supporting Information. The Supporting Information presents fuller details of the univariable models presented in Table 2 and the multivariable analyses in Tables 3 and 4. 
Table 1: Demographic characteristics, mental health and substance use characteristics of participants at baseline and follow-up

\begin{tabular}{|c|c|c|c|c|c|}
\hline \multirow[t]{2}{*}{ Variables } & & \multicolumn{2}{|c|}{ Baseline } & \multicolumn{2}{|l|}{ Follow-up } \\
\hline & & $\mathbf{N} \dagger$ & $\%$ & & $\%$ \\
\hline \multirow[t]{2}{*}{ Survey year } & B-CAMHS99 & 1124 & $31.2 \%$ & - & - \\
\hline & B-CAMHS04 & 2483 & $68.8 \%$ & - & - \\
\hline \multirow{3}{*}{ Country } & England & 3124 & $86.6 \%$ & - & - \\
\hline & Scotland & 368 & $10.2 \%$ & - & - \\
\hline & Wales & 115 & $3.2 \%$ & - & - \\
\hline \multirow[t]{2}{*}{ Gender } & Male & 1856 & $51.5 \%$ & - & - \\
\hline & Female & 1751 & $48.5 \%$ & - & - \\
\hline \multirow[t]{3}{*}{ Age at baseline } & 11 to 12 years & 1378 & $38.2 \%$ & - & - \\
\hline & 13 to 14 years & 1360 & $37.7 \%$ & - & - \\
\hline & 15 to 16 years & 869 & $24.1 \%$ & - & - \\
\hline \multirow[t]{6}{*}{ Ethnic group } & White & 3331 & $92.4 \%$ & - & - \\
\hline & Black & 59 & $1.6 \%$ & - & - \\
\hline & Indian & 60 & $1.7 \%$ & - & - \\
\hline & Pakistani or & & & - & - \\
\hline & Bangladeshi & 46 & $1.3 \%$ & & \\
\hline & Other & 110 & $3.1 \%$ & - & - \\
\hline Parent-reported & 0 points & 600 & $16.7 \%$ & 651 & $18.3 \%$ \\
\hline internalizing & 1-2 points & 1245 & $34.5 \%$ & 1294 & $36.3 \%$ \\
\hline \multirow[t]{6}{*}{ SDQ score } & 3-4 points & 784 & $21.8 \%$ & 779 & $21.9 \%$ \\
\hline & 5-6 points & 447 & $12.4 \%$ & 399 & $11.2 \%$ \\
\hline & 7-8 points & 244 & $6.8 \%$ & 220 & $6.2 \%$ \\
\hline & 9-11 points & 191 & $5.3 \%$ & 133 & $3.7 \%$ \\
\hline & $12-14$ points & 61 & $1.7 \%$ & 65 & $1.8 \%$ \\
\hline & $15-20$ points & 32 & $0.9 \%$ & 21 & $0.6 \%$ \\
\hline Parent-reported & 0 points & 487 & $13.5 \%$ & 527 & $14.8 \%$ \\
\hline externalizing & 1-2 points & 915 & $25.4 \%$ & 895 & $25.1 \%$ \\
\hline \multirow[t]{6}{*}{ SDQ score } & 3-4 points & 799 & $22.2 \%$ & 831 & $23.3 \%$ \\
\hline & 5-6 points & 571 & $15.9 \%$ & 538 & $15.1 \%$ \\
\hline & 7-8 points & 333 & $9.2 \%$ & 345 & $9.7 \%$ \\
\hline & 9-11 points & 291 & $8.1 \%$ & 269 & $7.6 \%$ \\
\hline & $12-14$ points & 132 & $3.7 \%$ & 104 & $2.9 \%$ \\
\hline & $15-20$ points & 74 & $2.1 \%$ & 52 & $1.5 \%$ \\
\hline \multirow[t]{2}{*}{ Emotional disorder } & No & 3363 & $93.2 \%$ & 3389 & $94.0 \%$ \\
\hline & Yes & 244 & $6.8 \%$ & 218 & $6.0 \%$ \\
\hline \multirow[t]{2}{*}{ Behavioral disorder } & No & 3372 & $93.5 \%$ & 3417 & $94.7 \%$ \\
\hline & Yes & 235 & $6.5 \%$ & 190 & $5.3 \%$ \\
\hline \multirow[t]{2}{*}{ Hyperactivity disorder } & No & 3522 & $97.6 \%$ & 3571 & $99.0 \%$ \\
\hline & Yes & 85 & $2.4 \%$ & 36 & $1.0 \%$ \\
\hline \multirow{4}{*}{ Regular smoker } & Never & 2892 & $85.9 \%$ & 2110 & $66.6 \%$ \\
\hline & Ex-smoker & 171 & $5.1 \%$ & 288 & $9.1 \%$ \\
\hline & Occasional & 111 & $3.3 \%$ & 228 & $7.2 \%$ \\
\hline & Regular smoker & 194 & $5.8 \%$ & 541 & $17.1 \%$ \\
\hline \multirow{3}{*}{$\begin{array}{l}\text { Frequent alcohol } \\
\text { consumption }\end{array}$} & No & & & & \\
\hline & & 3050 & $90.6 \%$ & 2892 & $91.4 \%$ \\
\hline & Yes & 315 & $9.4 \%$ & 273 & $8.6 \%$ \\
\hline \multirow[t]{3}{*}{ Cannabis use } & Never & 3158 & $93.9 \%$ & 2582 & $81.6 \%$ \\
\hline & Less than monthly & 103 & $3.1 \%$ & 300 & $9.5 \%$ \\
\hline & Monthly or more & 104 & $3.1 \%$ & 284 & $9.0 \%$ \\
\hline Ever used other & No & 3323 & $98.8 \%$ & 2963 & $93.6 \%$ \\
\hline illicit drug & Yes & 42 & $1.3 \%$ & 202 & $6.4 \%$ \\
\hline
\end{tabular}

$\dagger \mathrm{N}$ for some variables adds to less than 3607 due to missing data. 
Table 2: Mental health and substance use at three-year follow-up by characteristics at baseline



All p-values are for heterogeneity, from univariable logistic regression analyses. Univariable analyses including the SDQ are presented in the Supporting Information.

\section{Continuity in mental health and substance use over time}

While not the focus of this paper, Table 2 demonstrates the striking continuity in both substance use and mental health over time. Multivariable analyses revealed adjusted odds ratios (OR) from 2 to over 10 between substance use at baseline and substance use of the same sort at follow-up (see Supporting Information). The strong dose response effect of smoking at baseline upon smoking at follow-up was particularly notable. There were also strong, dose-response effects of smoking at baseline upon regular cannabis use at follow-up, and of cannabis use at baseline upon having taken other illicit drugs at follow-up. 
Mental health problems and disorders likewise showed strong continuity between baseline and follow-up; for example, the adjusted OR was 4.98 for internalizing disorders and 11.8 for behavioral disorders. For hyperactivity, the continuity between disorder at baseline and disorder at follow-up was so strong (unadjusted OR 364) that it was impossible to obtain stable effect estimates for any baseline variable.

\section{Effect of mental health upon future substance use}

Table 3 presents the effect of mental health at baseline upon substance use at follow-up, adjusting for baseline substance use, comorbidity and family confounders. The strongest effect was that youth with externalizing problems or behavioral disorders at baseline were more likely to be regular smokers at follow-up. For the externalizing SDQ subscale, the OR for regular smoking was 1.14 (95\% CI 1.10 to 1.17$)$ per one-point increase, corresponding to an OR of 1.61 per standard deviation increase. This effect was observed across the full range, as were the somewhat weaker associations with alcohol, cannabis, and other illicit drug use (see Figure 1). Analyses using the DAWBA bands indicated that these effects were driven by behavioral not hyperactivity problems, and replicated the finding of a doseresponse effect (Figure 1). This suggests that the lack of a significant effect of behavioral disorder upon alcohol, cannabis and other illicit drug use may reflect insufficient power to capture comparatively weak effects.

Table 3: Effect of mental health at baseline upon substance use at follow-up (adjusting for substance use at baseline): $\mathrm{N}=\mathbf{3 6 0 7}$

\begin{tabular}{|c|c|c|c|c|c|c|}
\hline & & & $\begin{array}{l}\text { Regular } \\
\text { smoker (OR } \\
\text { and } 95 \% \mathrm{CI}) \\
\end{array}$ & $\begin{array}{l}\text { Frequent alcohol } \\
\text { consumption }(\mathrm{OR} \\
\text { and } 95 \% \mathrm{CI})\end{array}$ & $\begin{array}{l}\text { Regular cannabis } \\
\text { use (OR and } 95 \% \\
\text { CI) }\end{array}$ & $\begin{array}{l}\text { Ever used other } \\
\text { illicit drug (OR } \\
\text { and } 95 \% \mathrm{CI})\end{array}$ \\
\hline \multirow{2}{*}{$\begin{array}{l}\text { Analyses } \\
\text { using the } \\
\text { Parent SDQ }\end{array}$} & $\begin{array}{l}\text { Internalizing SDQ } \\
\text { subscale }\end{array}$ & $\begin{array}{l}\text { Change per } \\
\text { SDQ point }\end{array}$ & $0.98(0.94,1.02)$ & $0.96(0.91,1.02)$ & $0.97(0.92,1.02)$ & $0.95(0.89,1.01)$ \\
\hline & $\begin{array}{l}\text { Externalizing SDQ } \\
\text { subscale }\end{array}$ & $\begin{array}{l}\text { Change per } \\
\text { SDQ point }\end{array}$ & $\begin{array}{r}1.14(1.10, \\
1.17)^{* * *} \\
\end{array}$ & $1.07(1.03,1.12)^{* * *}$ & $1.08(1.03,1.13)^{* *}$ & $1.08(1.02,1.14)^{* * *}$ \\
\hline \multirow{3}{*}{$\begin{array}{l}\text { Analyses } \\
\text { using the } \\
\text { DAWBA } \\
\text { probability } \\
\text { bands }\end{array}$} & $\begin{array}{l}\text { Internalizing } \\
\text { DAWBA band }\end{array}$ & $\begin{array}{l}\text { Change per } \\
\text { level }\end{array}$ & $1.08(0.91,1.28)$ & $0.93(0.75,1.16)$ & $1.02(0.82,1.28)$ & $0.95(0.72,1.25)$ \\
\hline & $\begin{array}{l}\text { Behavioral } \\
\text { DAWBA band }\end{array}$ & $\begin{array}{l}\text { Change per } \\
\text { level }\end{array}$ & $\begin{array}{r}1.48(1.23, \\
1.78)^{* * *} \\
\end{array}$ & $1.29(1.03,1.63)^{*}$ & $1.37(1.12,1.68)^{* *}$ & $1.32(1.00,1.74)^{*}$ \\
\hline & $\begin{array}{l}\text { Hyperactivity } \\
\text { DAWBA band }\end{array}$ & $\begin{array}{l}\text { Change per } \\
\text { level }\end{array}$ & $1.16(0.93,1.44)$ & $0.96(0.74,1.25)$ & $0.92(0.73,1.18)$ & $0.99(0.72,1.36)$ \\
\hline \multirow{6}{*}{$\begin{array}{l}\text { Analyses } \\
\text { using } \\
\text { clinical } \\
\text { diagnoses }\end{array}$} & Internalizing & No & $1 *$ & 1 & 1 & 1 \\
\hline & disorder & Yes & $1.65(1.08,2.52)$ & $1.01(0.52,1.95)$ & $1.01(0.57,1.81)$ & $1.37(0.72,2.58)$ \\
\hline & Behavioral & No & $1 * * *$ & 1 & 1 & 1 \\
\hline & disorder & Yes & $2.83(1.72,4.64)$ & $1.00(0.55,1.82)$ & $1.66(0.97,2.84)$ & $1.63(0.83,3.22)$ \\
\hline & Hyperactivity & No & 1 & 1 & 1 & 1 \\
\hline & disorder & Yes & $1.25(0.55,2.82)$ & $1.37(0.61,3.10)$ & $0.87(0.37,2.07)$ & $0.79(0.26,2.36)$ \\
\hline
\end{tabular}

$\mathrm{OR}=$ odds ratio. All models adjust for gender; age; baseline smoking, alcohol use, cannabis use and other illicit drug use; survey year; country; ethnic group; parent education; housing tenure; family type. For full results of the models using the SDQ and clinical diagnoses, see Supporting Information. 


\section{Figure 1: Adjusted odds ratio of substance use at follow-up by externalizing SDQ score at baseline}

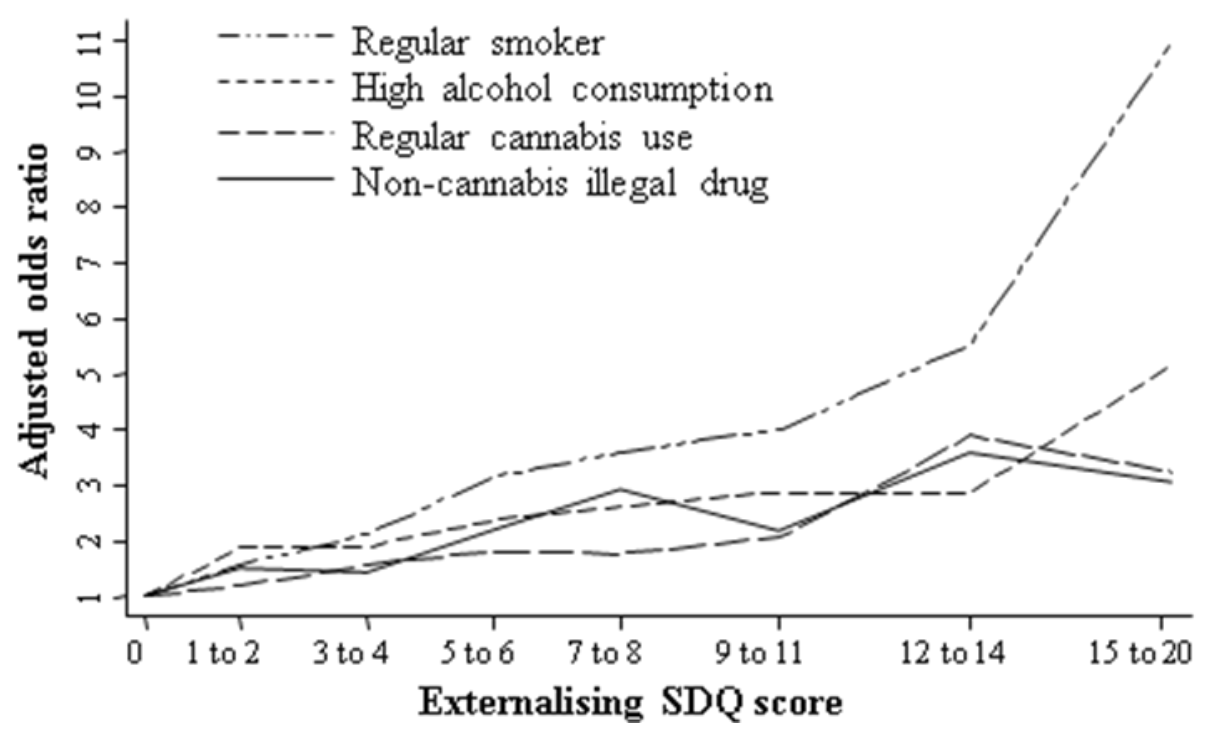

Odds ratios adjusted for baseline internalizing SDQ score, plus gender, age, baseline smoking, alcohol use, cannabis use and other illicit drug use, survey year, country, ethnic group, general health, parent mental health, family type, parent education, housing tenure. The models are therefore identical to those presented in Table 3, except that externalizing SDQ subscale was entered as a categorical variable rather than as a continuous term.

\section{Figure 2: Adjusted odds ratio of substance use at follow-up by parent DAWBA bands}

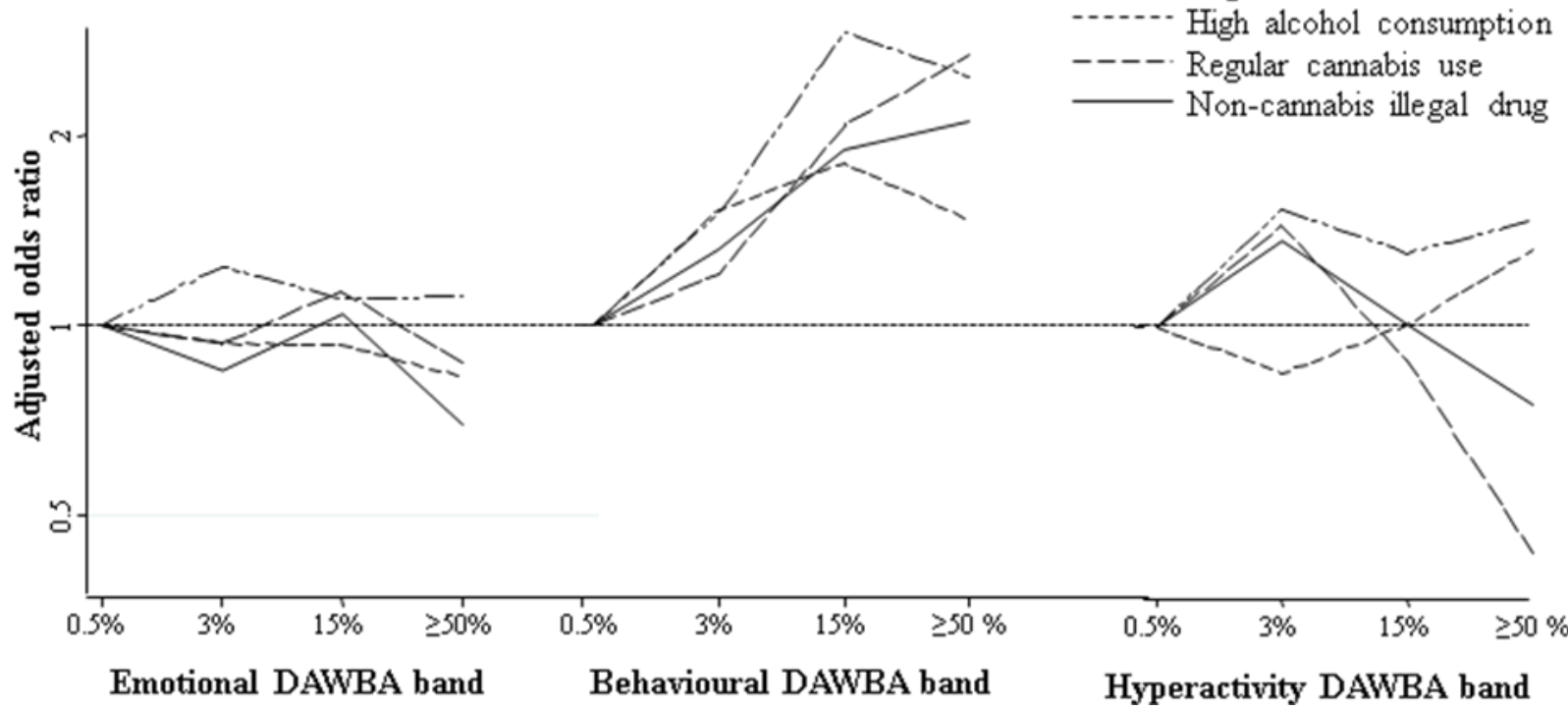

Odds ratios adjusted for other DAWBA bands, plus gender, age, baseline smoking, alcohol use, cannabis use and other illicit drug use, survey year, country, ethnic group, general health, parent mental health, family type, parent education, housing tenure. The models are therefore identical to those presented in Table 3, except that the DAWBA bands are entered as a categorical variables rather than continuous terms. 
Figure 3: Adjusted odds ratio of regular smoking at follow-up by internalizing SDQ score with and without adjustment for externalizing SDQ score

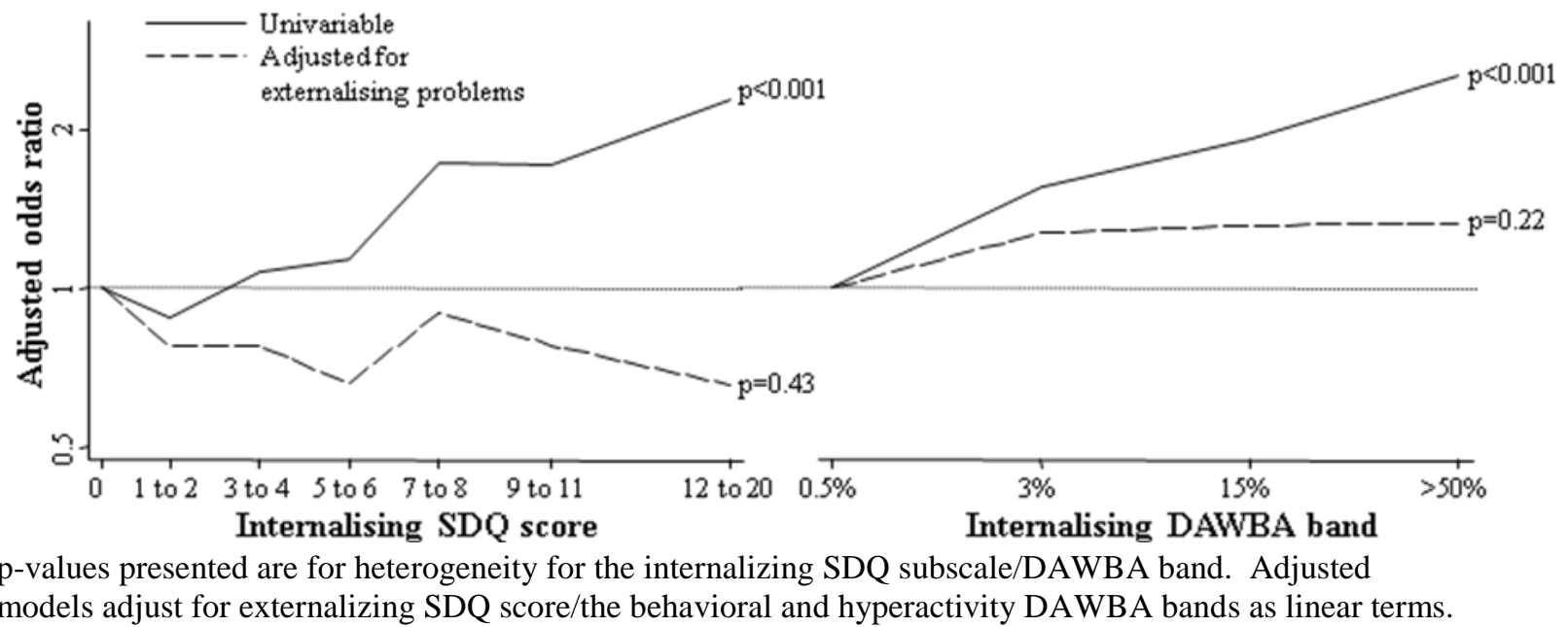

By contrast, there was no convincing evidence that internalizing problems or disorders predicted alcohol, cannabis or other illicit drug use. In univariable analyses, there was strong evidence $(\mathrm{p}<0.001)$ that the internalizing SDQ subscale and DAWBA band predicted smoking at follow-up. This disappeared entirely, however, after adjusting for externalizing problems (Figure 3$)$. The continued weak evidence $(\mathrm{p}=0.02)$ for an effect of internalizing disorder upon future smoking therefore seems likely to reflect residual confounding, caused by adjusting only for the relatively crude binary measures of behavioral or hyperactivity disorder.

\section{Effect of substance use upon future mental health}

Table 4 presents the effect of substance use at baseline upon mental health at follow-up, adjusting for substance use, comorbidity and family confounders at baseline. There was some evidence that other illicit drug use predicted internalizing problems or disorders. This effect was seen across all three internalizing outcomes; nevertheless in the context of multiple testing this weakly-significant finding should be interpreted with caution as it may represent a chance result. In no other case was there any evidence of an effect of substance use at baseline upon mental health at follow-up ( $p>0.15)$. 


\section{Interactions and sensitivity analyses}

None of the associations in Tables 3 and 4 showed evidence of an interaction with age or gender $(\mathrm{p}<0.01)$. The point estimates and substantive findings were very similar in sensitivity analyses using complete case analyses of those with no missing data $(\mathrm{N}=2890)$, or after restricting the SDQ analyses to those aged 13-16 at follow-up $(\mathrm{N}=2081)$. The predictors of regular smoking and regular cannabis use at follow-up were very similar to the predictors of lifetime smoking/cannabis use (see Supporting information). The predictors of mental disorder at follow-up were very similar between children with a disorder at baseline and those without, with no evidence of an interaction between presence/absence of baseline disorder and any substance use variable ( $p>0.15$; see Supporting information).

\section{$\underline{\text { Discussion }}$}

In this sample of 3607 British youth aged 11 to 16 , there was strong evidence that externalizing problems or disorders at baseline predicted smoking, alcohol, cannabis and other illicit drug use at three-year follow-up. This association was particularly strong for smoking, and was carried by behavioral problems; hyperactivity problems and disorders showed no independent effects. For all forms of substance use, externalizing/behavioral problems showed a dose-response relationship across the whole range. By contrast, there was little or no evidence of any independent effect of internalizing problems or disorders at baseline. Instead the strong univariable effects of internalizing problems upon smoking largely disappeared after adjusting for comorbid externalizing problems. There was also little evidence for independent effects of substance use at baseline upon mental health at followup. The only exception was that taking other illicit drugs increased the risk of internalizing problems and disorders.

In interpreting these findings, it is worth remembering this paper's limitations. The reliance on self-reported substance use could lead to information biases (e.g. over- or under-reporting by youth with mental health problems); future studies using objective measures such as saliva cotinine concentrations would be valuable to address this possibility. The substance use information in this study was also limited in including no information on substance abuse or dependence, which may have different predictors to substance use $(3,23,25)$. The mental health data was substantially richer, but some analyses using the rare, binary 'mental disorder' outcomes may have lacked power. This plausibly explained the failure to detect modest effects of behavioural disorder upon alcohol, cannabis and drug use. The lack of evidence of any difference in the predictors of disorder persistence and disorder incidence should likewise be treated with caution, as this study was not well-powered to examine this issue. Finally, although the onset of behavioral problems prior to substance use is consistent with a causal relationship, it may also reflect the operation of unmeasured confounders. In particular, this study cannot address the substantial role of shared genetic liability (39).

Yet although it cannot address the possibility of genetic confounding, this paper makes some novel contributions to our understanding of externalizing problems as predictors of substance use in adolescence. One is the demonstration that this effect of behavioral problems applies across the whole range. The Christchurch Health and Development Study has previously reported that behavioral problems at age 7-9 had a dose response effect upon nicotine and illicit drug dependence at ages 21-25, even after adjustment for multiple confounders \{Fergusson, 2005 \#1305\}. The Christchurch Study has also demonstrated a univariable dose response association between these childhood behavioural problems and tobacco, cannabis 
and other illicit drug use at age 18 (but no association with alcohol use) (6). To my knowledge, however, this is the first paper to show that dose response effects upon adolescent substance use persist even in multivariable analyses which adjust for multiple youth and family factors, including baseline substance use and comorbidity. This matters because several commentators have suggested the need for strategies to prevent teen smoking or drinking that focus on youth with marked behavioral problems (e.g. 7, 16). Yet if behavioral problems have an effect across the full range, then population-wide interventions which attempt to shift the distribution of the whole population may have more impact than interventions which target individuals at the extremes (60).

The B-CAMHS data also provides a dramatic illustration of why it is vital to adjust for comorbid externalizing problems when interpreting the effects of internalizing problems upon substance use. The dimensional and ordered mental health measures showed strong and highly significant univariable effects of internalizing problems, but these completely disappeared after adjusting for externalizing problems. By contrast, weakly significant effects remained for the clinical diagnosis of mental disorder, probably as a result of residual confounding. This both confirms the importance of adjusting for externalizing problems (61) and also warns against assuming that binary measures of disorder are adequate in this regard. Residual confounding may partly explain why some studies using binary measures of disorder report independent effects of internalizing problems $(1,10,25)$, while a larger number do not $(7,12,13,26,27)$. This study adds to the evidence of the latter studies, indicating that internalizing problems do not have an independent effect upon substance use in mid to late adolescence. This contrasts with findings in young adults $(2,34,62,63)$, highlighting the need to consider how the effects of different types of mental health problems may vary at different stages of development (7)\{Hayatbakhsh, 2008 \#1299\}.

Also in contrast with findings from young adults $(6,26,28-37)$ is the finding of this study that most forms of substance use do not predict mental health problems in adolescence. This is in line with some previous studies that examine mental health within adolescence $(7,37)$, and again indicates the possibility of differential effects at different stages of development. The one possible exception was some evidence of an increased risk of internalizing problems or disorders for youth who reported ever having taken a non-cannabis illicit drug at baseline. In the context of multiple testing this weakly-significant finding should be treated with some caution; nevertheless, it does replicate another recent British study which found that having tried drugs predicted depressive symptoms at two-year follow-up (38). Finally, this paper also replicated previous reports of co-occurrence of substance use, of strong continuity in substance use over time (40-42, 64), and of cross-substance effects of smoking upon cannabis use, and cannabis use upon other drugs $(1,64-67)$.

In conclusion, this paper adds further evidence that the most consistent longitudinal association between substance use and mental health in adolescence is one in which earlier behavioral problems predict later substance use. It further indicates that these effects were strongest upon smoking in this British sample, and showed a dose response effect across the full range. At least one randomised controlled trial has shown modest success in reducing smoking initiation through a universal intervention designed to prevent externalizing and other mental health problems in first grade children $(68,69)$. This paper strengthens the evidence-base for pursuing population-wide prevention programs of this sort. 


\section{Conflict of interest}

None

\section{$\underline{\text { Acknowledgements }}$}

The B-CAMHS surveys were carried out by the Office for National Statistics, and paid for by the Department of Health, the Scottish Health Executive, and the National Assembly for Wales (1999 survey only). AG carried out the analyses for this paper while funded by an Economic and Social Research Council/Medical Research Council Research Degree Studentship.

\section{$\underline{\text { References }}$}

1. Brown RA, Lewinsohn PM, Seeley JR, Wagner EF. Cigarette smoking, major depression, and other psychiatric disorders among adolescents. J Am Acad Child Adolesc Psychiatry. 1996 Dec;35(12):1602-10.

2. Bardone AM, Moffitt TE, Caspi A, Dickson N, Stanton WR, Silva PA. Adult physical health outcomes of adolescent girls with conduct disorder, depression, and anxiety. J Am Acad Child Adolesc Psychiatry. 1998 Jun;37(6):594-601.

3. Breslau N. Psychiatric comorbidity of smoking and nicotine dependence. Behav Genet. 1995 Mar;25(2):95-101.

4. Burke JD, Loeber R, White HR, Stouthamer-Loeber M, Pardini DA. Inattention as a key predictor of tobacco use in adolescence. J Abnorm Psychol. 2007 May;116(2):249-59. 5. Costello EJ, Erkanli A, Federman E, Angold A. Development of psychiatric comorbidity with substance abuse in adolescents: effects of timing and sex. J Clin Child Psychol. 1999 Sep;28(3):298-311.

6. Fergusson DM, Horwood LJ, Ridder EM. Conduct and attentional problems in childhood and adolescence and later substance use, abuse and dependence: results of a 25year longitudinal study. Drug Alcohol Depend. 2007 Apr;88 Suppl 1:S14-26.

7. Griesler PC, Hu MC, Schaffran C, Kandel DB. Comorbidity of psychiatric disorders and nicotine dependence among adolescents: findings from a prospective, longitudinal study. J Am Acad Child Adolesc Psychiatry. 2008 Nov;47(11):1340-50.

8. Storr CL, Reboussin BA, Anthony JC. Early childhood misbehavior and the estimated risk of becoming tobacco-dependent. Am J Epidemiol. 2004 Jul 15;160(2):126-30.

9. White HR, Xie M, Thompson W, Loeber R, Stouthamer-Loeber M. Psychopathology as a predictor of adolescent drug use trajectories. Psychol Addict Behav. 2001 Sep;15(3):2108 .

10. Wittchen H-U, Fröhlich C, Behrendt S, Günther A, Rehm J, Zimmermann P, et al. Cannabis use and cannabis use disorders and their relationship to mental disorders: A 10-year prospective-longitudinal community study in adolescents. Drug and Alcohol Dependence. 2007;88(Supplement 1):S60-S70.

11. Boyle MH, Offord DR, Racine YA, Szatmari P, Fleming JE, Links PS. Predicting substance use in late adolescence: results from the Ontario Child Health Study follow-up. Am J Psychiatry. 1992 Jun;149(6):761-7.

12. King SM, Iacono WG, McGue M. Childhood externalizing and internalizing psychopathology in the prediction of early substance use. Addiction. 2004 Dec;99(12):154859. 
13. Sung M, Erkanli A, Angold A, Costello EJ. Effects of age at first substance use and psychiatric comorbidity on the development of substance use disorders. Drug Alcohol Depend. 2004 Sep 6;75(3):287-99.

14. Pedersen W, Mastekaasa A, Wichstrom L. Conduct problems and early cannabis initiation: a longitudinal study of gender differences. Addiction. 2001 Mar;96(3):415-31.

15. Cohen P, Chen H, Crawford TN, Brook JS, Gordon K. Personality disorders in early adolescence and the development of later substance use disorders in the general population. Drug and Alcohol Dependence. 2007;88(Supplement 1):S71-S84.

16. Pardini D, White HR, Stouthamer-Loeber M. Early adolescent psychopathology as a predictor of alcohol use disorders by young adulthood. Drug Alcohol Depend. 2007 Apr;88 Suppl 1:S38-49.

17. Costello EJ, Sung M, Worthman C, Angold A. Pubertal maturation and the development of alcohol use and abuse. Drug and Alcohol Dependence. 2007;88(Supplement 1):S50-S9.

18. Fergusson DM, Boden JM, Horwood LJ. Recurrence of major depression in adolescence and early adulthood, and later mental health, educational and economic outcomes. Br J Psychiatry. 2007 Oct;191:335-42.

19. Henry B, Feehan M, McGee R, Stanton W, Moffitt TE, Silva P. The importance of conduct problems and depressive symptoms in predicting adolescent substance use. $\mathrm{J}$ Abnorm Child Psychol. 1993 Oct;21(5):469-80.

20. Flory K, Lynam DR. The relation between attention deficit hyperactivity disorder and substance abuse: what role does conduct disorder play? Clin Child Fam Psychol Rev. 2003 Mar;6(1):1-16.

21. Wang MQ, Fitzhugh EC, Green BL, Turner LW, Eddy JM, Westerfield RC. Prospective social-psychological factors of adolescent smoking progression. J Adolesc Health. 1999 Jan;24(1):2-9.

22. Patton GC, Carlin JB, Coffey C, Wolfe R, Hibbert M, Bowes G. Depression, anxiety, and smoking initiation: a prospective study over 3 years. Am J Public Health. 1998 Oct;88(10):1518-22.

23. Sonntag H, Wittchen HU, Hofler M, Kessler RC, Stein MB. Are social fears and DSM-IV social anxiety disorder associated with smoking and nicotine dependence in adolescents and young adults? Eur Psychiatry. 2000 Feb;15(1):67-74.

24. Hofler M, Lieb R, Perkonigg A, Schuster P, Sonntag H, Wittchen HU. Covariates of cannabis use progression in a representative population sample of adolescents: a prospective examination of vulnerability and risk factors. Addiction. 1999 Nov;94(11):1679-94.

25. Dierker LC, Vesel F, Sledjeski EM, Costello D, Perrine N. Testing the dual pathway hypothesis to substance use in adolescence and young adulthood. Drug Alcohol Depend. 2007 Feb 23;87(1):83-93.

26. Isensee B, Wittchen HU, Stein MB, Hofler M, Lieb R. Smoking increases the risk of panic: findings from a prospective community study. Arch Gen Psychiatry. 2003 Jul;60(7):692-700.

27. Achenbach TM, Howell CT, McConaughy SH, Stanger C. Six-year predictors of problems in a national sample: IV. Young adult signs of disturbance. J Am Acad Child Adolesc Psychiatry. 1998 Jul;37(7):718-27.

28. Patton GC, Coffey C, Carlin JB, Degenhardt L, Lynskey M, Hall W. Cannabis use and mental health in young people: cohort study. Bmj. 2002 Nov 23;325(7374):1195-8.

29. Brook JS, Cohen P, Brook DW. Longitudinal study of co-occurring psychiatric disorders and substance use. J Am Acad Child Adolesc Psychiatry. 1998 Mar;37(3):322-30.

30. Breslau N, Klein DF. Smoking and panic attacks: an epidemiologic investigation. Arch Gen Psychiatry. 1999 Dec;56(12):1141-7. 
31. Johnson JG, Cohen P, Pine DS, Klein DF, Kasen S, Brook JS. Association between cigarette smoking and anxiety disorders during adolescence and early adulthood. Jama. 2000 Nov 8;284(18):2348-51.

32. Breslau N, Novak SP, Kessler RC. Daily smoking and the subsequent onset of psychiatric disorders. Psychol Med. 2004 Feb;34(2):323-33.

33. Kandel DB, Davies M, Karus D, Yamaguchi K. The consequences in young adulthood of adolescent drug involvement. An overview. Arch Gen Psychiatry. 1986 Aug;43(8):746-54.

34. Breslau N, Peterson EL, Schultz LR, Chilcoat HD, Andreski P. Major depression and stages of smoking. A longitudinal investigation. Arch Gen Psychiatry. 1998 Feb;55(2):161-6. 35. Arseneault L, Cannon M, Poulton R, Murray R, Caspi A, Moffitt TE. Cannabis use in adolescence and risk for adult psychosis: longitudinal prospective study. Bmj. 2002 Nov 23;325(7374):1212-3.

36. Brook JS, Schuster E, Zhang C. Cigarette smoking and depressive symptoms: a longitudinal study of adolescents and young adults. Psychol Rep. 2004 Aug;95(1):159-66.

37. McGee R, Williams S, Poulton R, Moffitt T. A longitudinal study of cannabis use and mental health from adolescence to early adulthood. Addiction. 2000 Apr;95(4):491-503.

38. Clark C, Haines MM, Head J, Klineberg E, Arephin M, Viner R, et al. Psychological symptoms and physical health and health behaviours in adolescents: a prospective 2-year study in East London. Addiction. 2007 Jan;102(1):126-35.

39. Silberg J, Rutter M, D'Onofrio B, Eaves L. Genetic and environmental risk factors in adolescent substance use. J Child Psychol Psychiatry. 2003 Jul;44(5):664-76.

40. Boreham R, Shaw A, editors. Smoking, Drinking and Drug Use Among Young People in England in 2000. London: Stationery Office; 2001.

41. Anderson K, Plant M, Plant M. Associations between drinking, smoking and illicit drug use among adolescents in the Western Isles of Scotland: implications for harm minimization Journal of Substance Use. 1998;3(1):13-20.

42. Jackson KM, Sher KJ, Cooper ML, Wood PK. Adolescent alcohol and tobacco use: onset, persistence and trajectories of use across two samples. Addiction. 2002 May;97(5):517-31.

43. Robins LN, McEvoy L. Conduct problems as predictors of substance abuse. In:

Robins LN, Rutter M, editors. Straight and Devious Pathways from Childhood to Adolescence Cambridge Cambridge University Press; 1990. p. 182-204.

44. Boys A, Farrell M, Taylor C, Marsden J, Goodman R, Brugha T, et al. Psychiatric morbidity and substance use in young people aged 13-15 years: results from the Child and Adolescent Survey of Mental Health. Br J Psychiatry. 2003 Jun;182:509-17.

45. Green H, McGinnity A, Meltzer H, Ford T, Goodman R. Mental health of children and young people in Great Britain, 2004. Palgrave MacMillan; 2005.

46. Meltzer H, Gatward R, Goodman R, Ford T. Mental health of children and adolescents in Great Britain. London: The Stationery Office; 2000.

47. Meltzer H, Gatward R, Corbin T, Goodman R, Ford T. Persistence, onset, risk factors and outcomes of childhood mental disorders. London: The Stationery Office; 2003.

48. Parry-Langdon et al. Three years on: Survey of the development and emotional wellbeing of children and young people. Cardiff: Office for National Statistics; 2008.

49. Goodman R. The Strengths and Difficulties Questionnaire: a research note. J Child Psychol Psychiatry. 1997 Jul;38(5):581-6.

50. Goodman R. Psychometric properties of the strengths and difficulties questionnaire. J Am Acad Child Adolesc Psychiatry. 2001 Nov;40(11):1337-45.

51. Goodman A, Goodman R. Strengths and difficulties questionnaire as a dimensional measure of child mental health. J Am Acad Child Adolesc Psychiatry. 2009 Apr;48(4):400-3. 
52. Goodman R, Ford T, Richards H, Gatward R, Meltzer H. The Development and WellBeing Assessment: description and initial validation of an integrated assessment of child and adolescent psychopathology. J Child Psychol Psychiatry. 2000 Jul;41(5):645-55.

53. Ford T, Goodman R, Meltzer H. The British Child and Adolescent Mental Health Survey 1999: the prevalence of DSM-IV disorders. J Am Acad Child Adolesc Psychiatry. 2003 Oct;42(10):1203-11.

54. American Psychiatric Association. Diagnostic and Statistical Manual of Mental Disorders, 4th edition (DSM-IV). Washington, DC: American Psychiatric Association.; 1994. 55. Goddard E, Higgins V. Smoking, drinking and drug use among young teenagers in 1998, Volume I (England) and Volume II (Scotland). London: The Stationary Office; 1999. 56. Goldberg DP, Williams P. A user's guide to the General Health Questionnaire. Windsor: NFER-Nelson 1998.

57. Van Buuren S, Boshuizen HC, Knook DL. Multiple imputation of missing blood pressure covariates in survival analysis. Statistics in Medicine. 1999;18:681-94.

58. Royston P. Multiple imputation of missing values. Stata Journal. 2004;4:227-41.

59. Royston P. Multiple imputation of missing values: update. Stata Journal. 2005;5(2):188-201.

60. Rose G, Day S. The population mean predicts the number of deviant individuals. BMJ. 1990 Nov 3;301(6759):1031-4.

61. Costello EJ. Psychiatric predictors of adolescent and young adult drug use and abuse: what have we learned? Drug Alcohol Depend. 2007 Apr;88 Suppl 1:S97-9.

62. Ismail K, Sloggett A, De Stavola B. Do common mental disorders increase cigarette smoking? Results from five waves of a population-based panel cohort study. Am J Epidemiol. 2000 Oct 1;152(7):651-7.

63. Breslau N, Novak SP, Kessler RC. Psychiatric disorders and stages of smoking. Biol Psychiatry. 2004 Jan 1;55(1):69-76.

64. Wagner FA, Anthony JC. Into the world of illegal drug use: exposure opportunity and other mechanisms linking the use of alcohol, tobacco, marijuana, and cocaine. Am J Epidemiol. 2002 May 15;155(10):918-25.

65. Agrawal A, Neale MC, Prescott CA, Kendler KS. A twin study of early cannabis use and subsequent use and abuse/dependence of other illicit drugs. Psychol Med. 2004 Oct;34(7):1227-37.

66. Fergusson DM, Boden JM, Horwood LJ. Cannabis use and other illicit drug use: testing the cannabis gateway hypothesis. Addiction. 2006 Apr;101(4):556-69.

67. Lynskey MT, Heath AC, Bucholz KK, Slutske WS, Madden PA, Nelson EC, et al. Escalation of drug use in early-onset cannabis users vs co-twin controls. JAMA. 2003 Jan 2229;289(4):427-33.

68. Storr CL, Ialongo NS, Kellam SG, Anthony JC. A randomized controlled trial of two primary school intervention strategies to prevent early onset tobacco smoking. Drug Alcohol Depend. 2002 Mar 1;66(1):51-60.

69. Ialongo NS, Werthamer L, Kellam SG, Brown CH, Wang S, Lin Y. Proximal impact of two first-grade preventive interventions on the early risk behaviors for later substance abuse, depression, and antisocial behavior. Am J Community Psychol. 1999 Oct;27(5):599641. 


\section{SUPPORTING INFORMATION}

Box 1: Common child mental disorders covered by the DAWBA, assigned according to the Diagnostic and Statistical Manual of Mental Disorders, 4th edition (DSV-IV)

Internalizing disorders

Anxiety disorders

- Separation anxiety

- Specific phobia

- Social phobia

- Panic attacks

- Agoraphobia

- Post Traumatic Stress Disorder

- Obsessive-Compulsive Disorder

- Generalised Anxiety Disorder

- Anxiety disorder, not otherwise specified

Depression

- Depressive episode

- Depressive episode, not otherwise specified.

Behavioural disorders (sometimes grouped with hyperactivity and called 'externalizing' disorders)

- Oppositional defiant disorder

- Conduct disorder

- Disruptive Behaviour Disorder, not otherwise specified.

Hyperactivity (sometimes grouped with behavioural problems and called 'externalizing' disorders)

- Attention Deficit Hyperactive Disorder (ADHD) Combined Type

- ADHD Inattentive Type

- ADHD Hyperactive-Impulsive Type

- Hyperactive disorder, not otherwise specified 
Table 5: Comparison of youth in study population compared to all 11 to 16 year olds selected for follow-up

\begin{tabular}{|c|c|c|c|c|}
\hline Variables & & $\begin{array}{l}\text { All } 11 \text { to } 16 \text { year } \\
\text { olds selected for } \\
\text { follow-up, } N \dagger(\%)\end{array}$ & $\begin{array}{l}\text { Study population } \\
\text { for analyses } \mathrm{N}^{\dagger} \\
(\%)\end{array}$ & $\begin{array}{l}\text { Odds ratio \& } \\
95 \% \mathrm{CI} \text { for being in } \\
\text { the study population }\end{array}$ \\
\hline \multirow[t]{2}{*}{ Survey year } & B-CAMHS99 & $1783(30.6 \%)$ & $1124(31.2 \%)$ & 1 \\
\hline & B-CAMHSO4 & $4052(69.4 \%)$ & $2483(68.8 \%)$ & $1.08(0.93,1.25)$ \\
\hline \multirow[t]{3}{*}{ Country } & England & $5067(86.8 \%)$ & $3124(86.6 \%)$ & 1 \\
\hline & Scotland & $552(9.5 \%)$ & $368(10.2 \%)$ & $1.18(0.91,1.52)$ \\
\hline & Wales & $216(3.7 \%)$ & $115(3.2 \%)$ & $0.83(0.60,1.15)$ \\
\hline \multirow[t]{2}{*}{ Gender } & Male & $3033(52.0 \%)$ & $1856(51.5 \%)$ & 1 \\
\hline & Female & $2802(48.0 \%)$ & $1751(48.5 \%)$ & $1.00(0.88,1.14)$ \\
\hline \multirow[t]{3}{*}{ Age at baseline } & 11 to 12 years & $2127(36.5 \%)$ & $1378(38.2 \%)$ & $1 * * *$ \\
\hline & 13 to 14 years & $2074(35.5 \%)$ & $1360(37.7 \%)$ & $1.05(0.89,1.23)$ \\
\hline & 15 to 16 years & $1634(28.0 \%)$ & $869(24.1 \%)$ & $0.72(0.61,0.85)$ \\
\hline \multirow[t]{6}{*}{ Ethnic group } & White & $5203(89.2 \%)$ & $3331(92.4 \%)$ & $1 * * *$ \\
\hline & Black & $138(2.4 \%)$ & $59(1.6 \%)$ & $0.36(0.25,0.50)$ \\
\hline & Indian & $130(2.2 \%)$ & $60(1.7 \%)$ & $0.47(0.32,0.71)$ \\
\hline & Pakistani or & & & \\
\hline & Bangladeshi & $162(2.8 \%)$ & $46(1.3 \%)$ & $0.24(0.16,0.36)$ \\
\hline & Other & $201(3.5 \%)$ & $110(3.1 \%)$ & $0.72(0.53,0.98)$ \\
\hline \multirow{8}{*}{$\begin{array}{l}\text { Parent-reported } \\
\text { internalizing } \\
\text { SDQ score }\end{array}$} & 0 points & $923(15.9 \%)$ & $600(16.7 \%)$ & 1 \\
\hline & $1-2$ points & $1896(32.7 \%)$ & $1245(34.5 \%)$ & $1.06(0.88,1.29)$ \\
\hline & $3-4$ points & $1254(21.7 \%)$ & $784(21.8 \%)$ & $1.03(0.84,1.26)$ \\
\hline & 5-6 points & $752(13.0 \%)$ & $447(12.4 \%)$ & $0.97(0.76,1.25)$ \\
\hline & $7-8$ points & $423(7.3 \%)$ & $244(6.8 \%)$ & $1.06(0.80,1.39)$ \\
\hline & $9-11$ points & $355(6.1 \%)$ & $191(5.3 \%)$ & $0.93(0.69,1.27)$ \\
\hline & $12-14$ points & $124(2.1 \%)$ & $61(1.7 \%)$ & $0.86(0.56,1.33)$ \\
\hline & $15-20$ points & $64(1.1 \%)$ & $32(0.9 \%)$ & $0.89(0.45,1.73)$ \\
\hline \multirow{8}{*}{$\begin{array}{l}\text { Parent-reported } \\
\text { externalizing } \\
\text { SDQ score }\end{array}$} & 0 points & $698(12.1 \%)$ & $487(13.5 \%)$ & $1 * * *$ \\
\hline & 1-2 points & $1337(23.1 \%)$ & $915(25.4 \%)$ & $0.94(0.73,1.20)$ \\
\hline & 3-4 points & $1233(21.3 \%)$ & $799(22.2 \%)$ & $0.78(0.61,1.00)$ \\
\hline & $5-6$ points & $938(16.2 \%)$ & $571(15.9 \%)$ & $0.73(0.57,0.93)$ \\
\hline & $7-8$ points & $601(10.4 \%)$ & $333(9.2 \%)$ & $0.61(0.46,0.80)$ \\
\hline & 9-11 points & $542(9.4 \%)$ & $291(8.1 \%)$ & $0.55(0.41,0.73)$ \\
\hline & $12-14$ points & $287(5.0 \%)$ & $132(3.7 \%)$ & $0.43(0.31,0.62)$ \\
\hline & $15-20$ points & $148(2.6 \%)$ & $74(2.1 \%)$ & $0.71(0.45,1.13)$ \\
\hline \multirow[t]{4}{*}{ Regular smoker } & Never & $4202(83.7 \%)$ & $2892(85.9 \%)$ & $1 *$ \\
\hline & Ex-smoker & $286(5.7 \%)$ & $171(5.1 \%)$ & $0.78(0.59,1.03)$ \\
\hline & Occasional & $160(3.2 \%)$ & $111(3.3 \%)$ & $1.20(0.83,1.73)$ \\
\hline & Regular smoker & $370(7.4 \%)$ & $194(5.8 \%)$ & $0.72(0.53,0.96)$ \\
\hline & No & & & \\
\hline \multirow{2}{*}{ consumption } & & $4552(90.8 \%)$ & $3050(90.6 \%)$ & 1 \\
\hline & Yes & $461(9.2 \%)$ & $315(9.4 \%)$ & $1.22(0.98,1.51)$ \\
\hline \multirow[t]{3}{*}{ Cannabis use } & Never & $4638(92.5 \%)$ & $3158(93.9 \%)$ & 1 \\
\hline & Less than monthly & $178(3.6 \%)$ & $103(3.1 \%)$ & $0.82(0.57,1.19)$ \\
\hline & Monthly or more & $196(3.9 \%)$ & $104(3.1 \%)$ & $0.84(0.56,1.25)$ \\
\hline Ever used other & No & $4930(98.4 \%)$ & $3323(98.8 \%)$ & 1 \\
\hline illicit drug & Yes & $82(1.6 \%)$ & $42(1.3 \%)$ & $0.89(0.54,1.47)$ \\
\hline
\end{tabular}


Table 6: Mental health and substance use at three-year follow-up by characteristics at baseline: full results including the SDQ subscales

\begin{tabular}{|c|c|c|c|c|c|c|c|c|c|c|}
\hline \multicolumn{2}{|c|}{$\begin{array}{l}\text { CHARACTERISTICS AT } \\
\text { BASELINE }\end{array}$} & \multicolumn{9}{|c|}{ CHARACTERISTICS AT FOLLOW-UP } \\
\hline & & $\begin{array}{l}\text { Internalizing } \\
\text { SDQ (mean) }\end{array}$ & $\begin{array}{l}\text { Externalizin } \\
\text { g SDQ } \\
\text { (mean) }\end{array}$ & $\begin{array}{l}\text { Emotional } \\
\text { disorder } \\
(\%)\end{array}$ & $\begin{array}{l}\text { Behavioral } \\
\text { disorder } \\
(\%)\end{array}$ & $\begin{array}{l}\text { Hyperacti } \\
\text { vity } \\
\text { disorder } \\
(\%)\end{array}$ & $\begin{array}{l}\text { Regular } \\
\text { smoker } \\
(\%)\end{array}$ & $\begin{array}{l}\text { Frequent } \\
\text { alcohol } \\
\text { consumption } \\
(\%)\end{array}$ & $\begin{array}{l}\text { Regular } \\
\text { cannabis } \\
\text { use }(\%)\end{array}$ & $\begin{array}{l}\text { Ever used } \\
\text { other illicit } \\
\text { drug }(\%)\end{array}$ \\
\hline \multicolumn{2}{|l|}{ Full sample } & 2.9 & 3.9 & 5.4 & 4.5 & 0.8 & 17.6 & 8.8 & 9.8 & 6.9 \\
\hline \multirow[t]{4}{*}{ Gender } & Male & 2.7 & 4.4 & 3.6 & 5.4 & 1.1 & 15.8 & 10.9 & 12.4 & 7.4 \\
\hline & Female & 3.2 & 3.5 & 7.2 & 3.5 & 0.4 & 19.6 & 6.5 & 7.1 & 6.3 \\
\hline & $p$-value $[a]$ & $<0.001$ & $<0.001$ & $<0.001$ & 0.01 & 0.01 & 0.008 & $<0.001$ & $<0.001$ & 0.21 \\
\hline & $R$-squared & 0.007 & 0.02 & 0.02 & 0.008 & 0.02 & 0.004 & 0.01 & 0.01 & $<0.001$ \\
\hline \multirow[t]{5}{*}{ Age } & 11 to 12 years & 2.9 & 4.2 & 3.5 & 5.7 & 1.0 & 8.1 & 8.0 & 5.2 & 2.8 \\
\hline & 13 to 14 years & 3.0 & 4.0 & 6.7 & 4.0 & 0.7 & 19.4 & 8.9 & 11.1 & 6.2 \\
\hline & 15 to 16 years & 2.9 & 3.5 & 6.3 & 3.3 & 0.5 & 29.7 & 9.8 & 15.0 & 14.1 \\
\hline & $p$-value $[a]$ & 0.57 & $<0.001$ & $<0.001$ & 0.01 & 0.47 & $<0.001$ & 0.39 & $<0.001$ & $<0.001$ \\
\hline & $R$-squared & 0.0001 & 0.007 & 0.02 & 0.008 & 0.01 & 0.05 & 0.004 & 0.02 & 0.05 \\
\hline \multirow{10}{*}{$\begin{array}{l}\text { Parent } \\
\text { internalizing } \\
\text { SDQ subscale }\end{array}$} & 0 points & 1.2 & 2.8 & 1.5 & 2.0 & 0.2 & 16.5 & 10.4 & 11.0 & 7.5 \\
\hline & 1-2 points & 2.0 & 3.3 & 2.9 & 2.9 & 0.1 & 14.8 & 9.7 & 9.7 & 6.7 \\
\hline & 3-4 points & 2.9 & 3.9 & 4.8 & 2.5 & 0.4 & 17.5 & 8.6 & 8.5 & 7.7 \\
\hline & 5-6 points & 4.2 & 5.1 & 7.2 & 7.9 & 1.2 & 18.3 & 10.3 & 9.1 & 6.7 \\
\hline & $7-8$ points & 5.4 & 5.4 & 12.5 & 9.4 & 2.1 & 25.5 & 8.5 & 12.6 & 5.9 \\
\hline & 9-11 points & 6.7 & 5.9 & 16.9 & 11.4 & 2.0 & 25.3 & 6.7 & 11.0 & 7.8 \\
\hline & $12-14$ points & 8.4 & 8.4 & 26.2 & 18.3 & 11.3 & 34.3 & 11.7 & 12.0 & 4.8 \\
\hline & $15-20$ points & 9.5 & 8.0 & 24.9 & 24.1 & 11.9 & 25.0 & 2.3 & 8.6 & 6.7 \\
\hline & $p$-value [b] & $<0.001$ & $<0.001$ & $<0.001$ & $<0.001$ & $<0.001$ & $<0.001$ & 0.18 & 0.55 & 0.78 \\
\hline & $R$-squared & 0.35 & 0.12 & 0.09 & 0.08 & 0.14 & 0.01 & 0.002 & $<0.001$ & $<0.001$ \\
\hline \multirow{10}{*}{$\begin{array}{l}\text { Parent } \\
\text { externalizing } \\
\text { SDQ subscale }\end{array}$} & 0 points & 2.0 & 1.1 & 2.2 & 0.5 & 0.0 & 6.6 & 5.0 & 5.3 & 3.6 \\
\hline & $1-2$ points & 2.3 & 2.3 & 5.2 & 1.0 & 0.0 & 11.4 & 9.0 & 7.1 & 5.8 \\
\hline & 3-4 points & 2.7 & 3.4 & 4.1 & 1.8 & 0.0 & 15.3 & 8.8 & 9.1 & 5.7 \\
\hline & $5-6$ points & 3.1 & 4.9 & 5.0 & 3.6 & 0.0 & 21.7 & 10.6 & 11.2 & 8.5 \\
\hline & $7-8$ points & 3.7 & 6.0 & 7.2 & 6.2 & 1.1 & 27.3 & 11.5 & 12.3 & 10.6 \\
\hline & $9-11$ points & 4.2 & 7.8 & 6.5 & 13.4 & 2.5 & 28.1 & 13.1 & 14.8 & 9.3 \\
\hline & $12-14$ points & 5.5 & 9.5 & 16.6 & 25.2 & 8.9 & 41.0 & 12.2 & 24.9 & 15.6 \\
\hline & $15-20$ points & 6.8 & 11.7 & 18.3 & 51.3 & 13.2 & 54.2 & 14.0 & 23.4 & 12.2 \\
\hline & $p$-value [b] & $<0.001$ & $<0.001$ & $<0.001$ & $<0.001$ & $<0.001$ & $<0.001$ & $<0.001$ & $<0.001$ & $<0.001$ \\
\hline & $R$-squared & 0.11 & 0.48 & 0.03 & 0.25 & 0.33 & 0.07 & 0.009 & 0.03 & 0.02 \\
\hline
\end{tabular}




\begin{tabular}{|c|c|c|c|c|c|c|c|c|c|c|}
\hline Emotional & No & 2.8 & 3.8 & 4.3 & 4.0 & 0.6 & 16.6 & 8.8 & 9.7 & 6.5 \\
\hline \multirow[t]{3}{*}{ disorder } & Yes & 6.3 & 6.3 & 29.3 & 14.2 & 3.9 & 40.0 & 7.9 & 13.3 & 13.5 \\
\hline & $p$-value $[a]$ & $<0.001$ & $<0.001$ & $<0.001$ & $<0.001$ & $<0.001$ & $<0.001$ & 0.66 & 0.14 & 0.005 \\
\hline & $R$-squared & 0.08 & 0.03 & 0.08 & 0.02 & 0.02 & 0.02 & $<0.001$ & 0.001 & 0.005 \\
\hline \multirow{4}{*}{$\begin{array}{l}\text { Behavioral } \\
\text { disorder }\end{array}$} & No & 2.8 & 3.7 & 4.9 & 2.9 & 0.4 & 16.0 & 9.3 & 9.1 & 6.5 \\
\hline & Yes & 5.5 & 9.2 & 15.6 & 37.6 & 9.5 & 53.5 & 11.6 & 25.8 & 18.7 \\
\hline & $p$-value $[a]$ & $<0.001$ & $<0.001$ & $<0.001$ & $<0.001$ & $<0.001$ & $<0.001$ & 0.35 & $<0.001$ & $<0.001$ \\
\hline & $R$-squared & 0.05 & 0.14 & 0.02 & 0.18 & 0.19 & 0.04 & $<0.001$ & 0.02 & 0.02 \\
\hline \multirow{4}{*}{$\begin{array}{l}\text { Hyperactivity } \\
\text { disorder }\end{array}$} & No & 2.9 & 3.8 & 5.3 & 3.9 & 0.1 & 17.2 & 9.3 & 9.7 & 6.9 \\
\hline & Yes & 6.2 & 10.4 & 8.6 & 35.9 & 34.7 & 39.5 & 13.8 & 18.0 & 11.3 \\
\hline & $p$-value $[a]$ & $<0.001$ & $<0.001$ & 0.21 & $<0.001$ & $<0.001$ & $<0.001$ & 0.22 & 0.03 & 0.21 \\
\hline & $R$-squared & 0.02 & 0.08 & 0.009 & 0.06 & 0.48 & 0.004 & 0.004 & 0.003 & 0.003 \\
\hline \multirow[t]{6}{*}{ Smoking } & Never & 2.8 & 3.8 & 4.8 & 4.0 & 0.7 & 10.8 & 8.7 & 6.5 & 4.3 \\
\hline & Ex-smoker & 3.2 & 4.9 & 6.9 & 8.1 & 1.6 & 41.4 & 11.8 & 23.2 & 16.2 \\
\hline & Occasional & 3.1 & 4.1 & 7.2 & 6.2 & 0.9 & 49.5 & 13.1 & 27.6 & 16.1 \\
\hline & Regular smoker & 3.9 & 5.8 & 11.7 & 8.2 & 0.5 & 84.2 & 15.8 & 40.0 & 36.4 \\
\hline & $p$-value $[a]$ & $<0.001$ & $<0.001$ & $<0.001$ & 0.01 & 0.61 & $<0.001$ & 0.009 & $<0.001$ & $<0.001$ \\
\hline & $R$-squared & 0.007 & 0.02 & 0.01 & 0.01 & 0.009 & 0.19 & 0.009 & 0.09 & 0.12 \\
\hline \multirow{4}{*}{$\begin{array}{l}\text { Frequent alcohol } \\
\text { consumption }\end{array}$} & No & 2.9 & 3.9 & 5.2 & 4.4 & 0.8 & 16.2 & 7.7 & 8.6 & 6.0 \\
\hline & Yes & 2.8 & 4.7 & 7.0 & 5.2 & 0.8 & 31.9 & 19.3 & 21.6 & 15.8 \\
\hline & $p$-value $[a]$ & 0.45 & 0.001 & 0.16 & 0.52 & 0.99 & $<0.001$ & $<0.001$ & $<0.001$ & $<0.001$ \\
\hline & $R$-squared & 0.0001 & 0.005 & 0.002 & 0.004 & $<0.001$ & 0.01 & 0.02 & 0.02 & 0.02 \\
\hline \multirow[t]{5}{*}{ Cannabis use } & Never & 2.9 & 3.9 & 5.1 & 4.3 & 0.8 & 15.0 & 9.0 & 7.7 & 4.9 \\
\hline & Less than monthly & 3.2 & 4.4 & 6.2 & 6.8 & 1.1 & 43.3 & 11.7 & 32.3 & 24.3 \\
\hline & Monthly or more & 3.7 & 5.0 & 13.3 & 6.1 & 1.0 & 75.9 & 20.3 & 55.0 & 57.1 \\
\hline & $p$-value $[a]$ & 0.03 & 0.02 & 0.002 & 0.42 & 0.90 & $<0.001$ & 0.03 & $<0.001$ & $<0.001$ \\
\hline & $R$-squared & 0.002 & 0.003 & 0.01 & 0.001 & 0.003 & 0.06 & 0.008 & 0.08 & 0.12 \\
\hline \multirow{5}{*}{$\begin{array}{l}\text { Ever used other } \\
\text { illicit drug }\end{array}$} & No & 2.9 & 3.9 & 5.2 & 4.4 & 0.8 & 16.9 & 8.7 & 9.3 & 6.2 \\
\hline & Yes & & & & & [empty & & & & \\
\hline & & 4.6 & 5.6 & 22.3 & 8.6 & cell] & 76.1 & 15.7 & 50.5 & 60.0 \\
\hline & $p$-value $[a]$ & 0.006 & 0.02 & $<0.001$ & 0.18 & 0.59 & $<0.001$ & 0.15 & $<0.001$ & $<0.001$ \\
\hline & $R$-squared & 0.005 & 0.003 & 0.01 & 0.002 & - & 0.03 & 0.001 & 0.03 & 0.06 \\
\hline
\end{tabular}

[a] P-value for heterogeneity; [b] p-value for linear trend. P-values and R-squared from univariable regression analyses, using linear regression analyses and R-squared values for SDQ subscales, and logistic regression and pseudo R-squared values for mental disorders and substance use outcomes. The only exception was for illicit drug use at baseline and hyperactivity disorder at follow-up, where the empty cell meant that I used an exact Fisher's chi-squared test. 
Table 7: Predicting to substance use at follow-up, using parent SDQ scores: full results



$\mathrm{OR}=$ odds ratio. $\dagger$ No Indian, Pakistani or Bangladeshi youth reported frequent alcohol use or other illicit drug use at follow-up, and these groups were therefore combined with youth of Other ethnicity when fitting multivariable models. 
Table 8: Predicting to substance use at follow-up, using clinical diagnoses: full results

\begin{tabular}{|c|c|c|c|c|c|}
\hline & & $\begin{array}{l}\text { Regular smoker } \\
\text { (OR and 95\% CI) }\end{array}$ & $\begin{array}{l}\text { Frequent alcohol } \\
\text { consumption }(\mathrm{OR} \\
\text { and } 95 \% \mathrm{CI})\end{array}$ & $\begin{array}{l}\text { Regular cannabis } \\
\text { use (OR and } 95 \% \\
\text { CI) }\end{array}$ & $\begin{array}{l}\text { Ever used other } \\
\text { illicit drug (OR } \\
\text { and } 95 \% \mathrm{CI})\end{array}$ \\
\hline \multirow[t]{2}{*}{ Gender } & Male & 1 & $1 * *$ & $1 * * *$ & 1 \\
\hline & Female & $1.22(0.96,1.54)$ & $0.59(0.43,0.80)$ & $0.49(0.36,0.66)$ & $0.83(0.58,1.18)$ \\
\hline \multirow[t]{3}{*}{ Age at baseline } & 11 to 12 years & $1 * * *$ & 1 & $1 * *$ & $1 *$ \\
\hline & 13 to 14 years & $2.07(1.53,2.78)$ & $1.23(0.88,1.71)$ & $1.81(1.26,2.61)$ & $1.67(1.01,2.76)$ \\
\hline & 15 to 16 years & $2.10(1.48,2.98)$ & $1.27(0.84,1.93)$ & $1.58(1.02,2.44)$ & $2.38(1.35,4.18)$ \\
\hline \multirow{2}{*}{$\begin{array}{l}\text { Emotional } \\
\text { disorder }\end{array}$} & No & $1 *$ & 1 & 1 & 1 \\
\hline & Yes & $1.65(1.08,2.52)$ & $1.01(0.52,1.95)$ & $1.01(0.57,1.81)$ & $1.37(0.72,2.58)$ \\
\hline \multirow{2}{*}{$\begin{array}{l}\text { Behavioral } \\
\text { disorder }\end{array}$} & No & $1 * * *$ & 1 & 1 & 1 \\
\hline & Yes & $2.83(1.72,4.64)$ & $1.00(0.55,1.82)$ & $1.66(0.97,2.84)$ & $1.63(0.83,3.22)$ \\
\hline \multirow{2}{*}{$\begin{array}{l}\text { Hyperactivity } \\
\text { disorder }\end{array}$} & No & 1 & 1 & 1 & 1 \\
\hline & Yes & $1.25(0.55,2.82)$ & $1.37(0.61,3.10)$ & $0.87(0.37,2.07)$ & $0.79(0.26,2.36)$ \\
\hline \multirow[t]{4}{*}{ Smoking } & Never & $1 * * *$ & 1 & $1 * * *$ & $1 *$ \\
\hline & Ex-smoker & $3.65(2.44,5.46)$ & $1.29(0.67,2.47)$ & $2.94(1.74,4.99)$ & $2.29(1.18,4.47)$ \\
\hline & Occasional & $5.81(3.46,9.76)$ & $1.13(0.55,2.32)$ & $3.30(1.64,6.64)$ & $1.98(0.88,4.45)$ \\
\hline & Regular smoker & $19.65(11.28,34.22)$ & $1.50(0.75,2.99)$ & $3.97(2.15,7.33)$ & $2.68(1.30,5.54)$ \\
\hline \multirow{2}{*}{$\begin{array}{l}\text { Frequent alcohol } \\
\text { consumption }\end{array}$} & No & 1 & $1 * *$ & 1 & 1 \\
\hline & Yes & $1.20(0.81,1.78)$ & $1.99(1.33,2.96)$ & $1.48(0.99,2.21)$ & $1.29(0.77,2.18)$ \\
\hline \multirow[t]{3}{*}{ Cannabis use } & Never & 1 & 1 & $1 * *$ & 1 1*** \\
\hline & Less than monthly & $0.91(0.46,1.83)$ & $0.86(0.35,2.12)$ & $2.14(1.15,3.99)$ & $2.23(1.07,4.64)$ \\
\hline & Monthly or more & $1.37(0.64,2.93)$ & $1.53(0.65,3.63)$ & $3.78(1.96,7.30)$ & $5.87(2.97,11.57)$ \\
\hline \multirow{2}{*}{$\begin{array}{l}\text { Ever used other } \\
\text { illicit drug }\end{array}$} & No & 1 & 1 & 1 & $1 * *$ \\
\hline & Yes & $2.32(0.76,7.08)$ & $0.82(0.27,2.45)$ & $1.43(0.60,3.39)$ & $3.57(1.42,8.97)$ \\
\hline \multirow[t]{2}{*}{ Survey year } & B-CAMHS99 & 1 & $1 *$ & $1 * *$ & 1 \\
\hline & B-CAMHS04 & $0.99(0.75,1.30)$ & $0.71(0.53,0.96)$ & $0.58(0.42,0.79)$ & $1.08(0.70,1.67)$ \\
\hline \multirow[t]{3}{*}{ Country } & England & 1 & 1 & 1 & 1 \\
\hline & Scotland & $0.91(0.57,1.45)$ & $0.69(0.41,1.16)$ & $0.96(0.62,1.48)$ & $0.79(0.40,1.57)$ \\
\hline & Wales & $1.17(0.69,1.97)$ & $0.49(0.15,1.58)$ & $0.76(0.29,1.97)$ & $1.15(0.42,3.13)$ \\
\hline \multirow[t]{6}{*}{ Ethnic group } & White & $1 *$ & $1 * *$ & 1 & 1 \\
\hline & Black & $0.10(0.01,0.74)$ & $0.14(0.02,1.11)$ & $1.43(0.50,4.09)$ & $0.48(0.05,4.45)$ \\
\hline & Indian $\dagger$ & $0.17(0.02,1.45)$ & & $0.60(0.12,3.03)$ & \\
\hline & Pakistani or & & & & \\
\hline & Bangladeshi† & $0.69(0.16,2.88)$ & & $0.18(0.02,1.78)$ & \\
\hline & Other & $0.61(0.25,1.48)$ & $0.18(0.05,0.62)$ & $0.89(0.36,2.21)$ & $0.78(0.30,2.03)$ \\
\hline $\begin{array}{l}\text { Good general } \\
\text { health }\end{array}$ & Change per level & $0.96(0.80,1.15)$ & $1.13(0.88,1.46)$ & $1.11(0.87,1.43)$ & $1.14(0.85,1.52)$ \\
\hline $\begin{array}{l}\text { Parent mental } \\
\text { health }\end{array}$ & Change per point & $1.03(0.99,1.07)$ & $1.00(0.95,1.05)$ & $0.99(0.94,1.04)$ & $1.02(0.95,1.08)$ \\
\hline \multirow[t]{3}{*}{ Family type } & Two-parent & $1 * * *$ & 1 & 1 & 1 \\
\hline & Lone parent & $1.91(1.33,2.76)$ & $1.16(0.75,1.81)$ & $1.51(0.99,2.29)$ & $1.27(0.79,2.05)$ \\
\hline & Step family & $1.94(1.43,2.63)$ & $1.08(0.73,1.60)$ & $1.16(0.79,1.69)$ & $1.16(0.72,1.85)$ \\
\hline \multirow{4}{*}{$\begin{array}{l}\text { Parent's highest } \\
\text { educational } \\
\text { level }\end{array}$} & No qualifications & 1 & 1 & 1 & 1 \\
\hline & GCSEs & $0.97(0.70,1.33)$ & $1.11(0.73,1.66)$ & $1.02(0.69,1.50)$ & $0.86(0.53,1.41)$ \\
\hline & A-levels/diploma & $0.84(0.59,1.20)$ & $1.15(0.73,1.82)$ & $1.15(0.74,1.80)$ & $0.83(0.46,1.48)$ \\
\hline & Degree & $0.75(0.48,1.18)$ & $1.31(0.79,2.19)$ & $1.47(0.90,2.38)$ & $1.19(0.63,2.25)$ \\
\hline \multirow[t]{2}{*}{ Housing tenure } & Owner occupied & 1 & $1 * *$ & 1 & 1 \\
\hline & Rented & $1.14(0.84,1.55)$ & $0.49(0.31,0.78)$ & $1.05(0.74,1.49)$ & $0.74(0.44,1.24)$ \\
\hline
\end{tabular}

$\mathrm{OR}=$ odds ratio. $\dagger$ No Indian, Pakistani or Bangladeshi youth reported frequent alcohol use or other illicit drug use at follow-up, and these groups were therefore combined with youth of Other ethnicity when fitting multivariable models. 
Table 9: Predicting to Mental health at follow-up, using parent SDQ scores: full results

\begin{tabular}{|c|c|c|c|}
\hline & & $\begin{array}{r}\text { Internalizing SDQ } \\
\text { subscale (regression } \\
\text { coefficient \& 95\% CI) }\end{array}$ & $\begin{array}{r}\text { Externalizing SDQ } \\
\text { subscale (regression } \\
\text { coefficient \& 95\% CI) }\end{array}$ \\
\hline \multirow[t]{2}{*}{ Gender } & Male & $0 * * *$ & $0 *$ \\
\hline & Female & $0.64(0.45,0.82)$ & $-0.20(-0.37,-0.02)$ \\
\hline \multirow[t]{3}{*}{ Age at baseline } & 11 to 12 years & 0 & $0 * * *$ \\
\hline & 13 to 14 years & $0.11(-0.08,0.30)$ & $-0.18(-0.39,0.02)$ \\
\hline & 15 to 16 years & $0.10(-0.12,0.33)$ & $-0.43(-0.66,-0.20)$ \\
\hline $\begin{array}{l}\text { Internalizing SDQ } \\
\text { subscale }\end{array}$ & $\begin{array}{l}\text { Change per SDQ } \\
\text { point }\end{array}$ & $0.47(0.43,0.51) * * *$ & $0.03(-0.01,0.06)$ \\
\hline $\begin{array}{l}\text { Externalizing SDQ } \\
\text { subscale }\end{array}$ & $\begin{array}{l}\text { Change per SDQ } \\
\text { point }\end{array}$ & $0.07(0.04,0.10) * * *$ & $0.62(0.58,0.65)^{* * *}$ \\
\hline \multirow[t]{4}{*}{ Smoking } & Never & 0 & 0 \\
\hline & Ex-smoker & $-0.13(-0.50,0.24)$ & $0.15(-0.36,0.65)$ \\
\hline & Occasional & $0.04(-0.39,0.47)$ & $-0.16(-0.75,0.44)$ \\
\hline & Regular smoker & $-0.17(-0.67,0.33)$ & $-0.01(-0.64,0.61)$ \\
\hline \multirow{2}{*}{$\begin{array}{l}\text { Frequent alcohol } \\
\text { consumption }\end{array}$} & No & 0 & 0 \\
\hline & Yes & $-0.15(-0.41,0.12)$ & $0.16(-0.18,0.50)$ \\
\hline \multirow[t]{3}{*}{ Cannabis use } & Never & 0 & 0 \\
\hline & Less than monthly & $0.31(-0.20,0.82)$ & $-0.08(-0.69,0.54)$ \\
\hline & Monthly or more & $0.32(-0.36,1.00)$ & $-0.26(-1.10,0.59)$ \\
\hline \multirow{2}{*}{$\begin{array}{l}\text { Ever used other } \\
\text { illicit drug }\end{array}$} & No & $0 *$ & 0 \\
\hline & Yes & $1.12(0.04,2.21)$ & $0.43(-0.89,1.75)$ \\
\hline \multirow[t]{2}{*}{ Survey year } & B-CAMHS99 & 0 & $0 * * *$ \\
\hline & B-CAMHS04 & $0.17(-0.02,0.35)$ & $0.59(0.39,0.79)$ \\
\hline \multirow[t]{3}{*}{ Country } & England & 0 & 0 \\
\hline & Scotland & $-0.12(-0.40,0.16)$ & $-0.01(-0.31,0.29)$ \\
\hline & Wales & $-0.14(-0.60,0.32)$ & $0.00(-0.55,0.55)$ \\
\hline \multirow[t]{6}{*}{ Ethnic group } & White & 0 & 0 \\
\hline & Black & $-0.32(-0.84,0.20)$ & $-0.20(-0.86,0.46)$ \\
\hline & Indian & $0.12(-0.57,0.81)$ & $-0.09(-0.61,0.42)$ \\
\hline & Pakistani or & & \\
\hline & Bangladeshi & $0.84(-0.01,1.68)$ & $0.25(-0.88,1.37)$ \\
\hline & Other & $-0.07(-0.52,0.38)$ & $0.10(-0.51,0.72)$ \\
\hline Good general health & Change per level & $-0.33(-0.51,-0.15)^{* * *}$ & $-0.06(-0.22,0.11)$ \\
\hline Parent mental health & Change per point & $0.06(0.02,0.10)^{* *}$ & $0.03(-0.01,0.07)$ \\
\hline \multirow[t]{3}{*}{ Family type } & Two-parent & 0 & 0 \\
\hline & Lone parent & $0.13(-0.16,0.42)$ & $0.23(-0.08,0.54)$ \\
\hline & Step family & $-0.12(-0.36,0.12)$ & $0.12(-0.14,0.38)$ \\
\hline \multirow{4}{*}{$\begin{array}{l}\text { Parent's highest } \\
\text { educational } \\
\text { level }\end{array}$} & No qualifications & 0 & $0^{*}$ \\
\hline & GCSEs & $-0.24(-0.50,0.02)$ & $-0.34(-0.63,-0.04)$ \\
\hline & A-levels/diploma & $-0.38(-0.68,-0.09)$ & $-0.41(-0.71,-0.10)$ \\
\hline & Degree & $-0.17(-0.49,0.15)$ & $-0.51(-0.85,-0.18)$ \\
\hline \multirow{2}{*}{ Housing tenure } & Owner occupied & 0 & 0 \\
\hline & Rented & $0.23(-0.02,0.48)$ & $0.15(-0.12,0.43)$ \\
\hline
\end{tabular}


Table 10: Predicting to Mental health at follow-up, using clinical diagnoses: full results

\begin{tabular}{|c|c|c|c|}
\hline & & $\begin{array}{l}\text { Emotional disorder } \\
(\text { OR \& 95\% CI })\end{array}$ & $\begin{array}{l}\text { Behavioral disorder } \\
\text { (OR \& 95\% CI) }\end{array}$ \\
\hline \multirow[t]{2}{*}{ Gender } & Male & $1 * * *$ & 1 \\
\hline & Female & $2.09(1.49,2.93)$ & $0.83(0.57,1.22)$ \\
\hline \multirow[t]{3}{*}{ Age at baseline } & 11 to 12 years & $1^{*}$ & $1 * *$ \\
\hline & 13 to 14 years & $1.74(1.18,2.57)$ & $0.57(0.37,0.89)$ \\
\hline & 15 to 16 years & $1.61(1.00,2.59)$ & $0.43(0.24,0.77)$ \\
\hline \multirow{2}{*}{$\begin{array}{l}\text { Emotional } \\
\text { disorder }\end{array}$} & No & $1 * * *$ & 1 \\
\hline & Yes & $4.98(3.21,7.72)$ & $1.66(0.94,2.92)$ \\
\hline \multirow{2}{*}{$\begin{array}{l}\text { Behavioral } \\
\text { disorder }\end{array}$} & No & $1 *$ & $1 * * *$ \\
\hline & Yes & $1.97(1.07,3.61)$ & $11.82(7.07,19.73)$ \\
\hline \multirow{2}{*}{$\begin{array}{l}\text { Hyperactivity } \\
\text { disorder }\end{array}$} & No & 1 & $1 *$ \\
\hline & Yes & $0.87(0.32,2.36)$ & $2.60(1.20,5.65)$ \\
\hline \multirow[t]{4}{*}{ Smoking } & Never & 1 & 1 \\
\hline & Ex-smoker & $0.88(0.43,1.79)$ & $1.84(0.88,3.83)$ \\
\hline & Occasional & $1.18(0.49,2.84)$ & $1.74(0.60,5.08)$ \\
\hline & Regular smoker & $0.77(0.36,1.64)$ & $0.83(0.32,2.14)$ \\
\hline \multirow{2}{*}{$\begin{array}{l}\text { Frequent alcohol } \\
\text { consumption }\end{array}$} & No & 1 & 1 \\
\hline & Yes & $1.40(0.85,2.31)$ & $1.06(0.55,2.05)$ \\
\hline \multirow[t]{3}{*}{ Cannabis use } & Never & 1 & 1 \\
\hline & Less than monthly & $0.75(0.30,1.92)$ & $1.26(0.38,4.16)$ \\
\hline & Monthly or more & $1.00(0.37,2.67)$ & $0.65(0.17,2.52)$ \\
\hline \multirow{2}{*}{$\begin{array}{l}\text { Ever used other } \\
\text { illicit drug }\end{array}$} & No & $1 *$ & 1 \\
\hline & Yes & $4.06(1.31,12.56)$ & $1.31(0.26,6.65)$ \\
\hline \multirow[t]{2}{*}{ Survey year } & B-CAMHS99 & 1 & $1 *$ \\
\hline & B-CAMHS04 & $1.10(0.76,1.60)$ & $0.66(0.45,0.99)$ \\
\hline \multirow{3}{*}{ Country } & England & 1 & 1 \\
\hline & Scotland & $0.87(0.51,1.51)$ & $0.73(0.36,1.47)$ \\
\hline & Wales & $0.81(0.33,1.95)$ & $0.43(0.14,1.37)$ \\
\hline \multirow[t]{6}{*}{ Ethnic group } & White & 1 & 1 \\
\hline & Black & $1.43(0.48,4.24)$ & $0.43(0.10,1.80)$ \\
\hline & Indian & $0.61(0.12,3.18)$ & $0.57(0.06,5.08)$ \\
\hline & Pakistani or & & \\
\hline & Bangladeshi & $1.18(0.39,3.64)$ & $1.21(0.17,8.60)$ \\
\hline & Other & $1.09(0.40,2.95)$ & $1.52(0.62,3.72)$ \\
\hline Good general health & Change per level & $0.64(0.51,0.80) * * *$ & $0.74(0.59,0.93)^{*}$ \\
\hline Parent mental health & Change per point & $1.11(1.06,1.17)^{* * *}$ & $1.02(0.96,1.08)$ \\
\hline \multirow[t]{3}{*}{ Family type } & Two-parent & 1 & 1 \\
\hline & Lone parent & $1.16(0.70,1.92)$ & $1.23(0.73,2.06)$ \\
\hline & Step family & $1.25(0.80,1.95)$ & $1.18(0.74,1.89)$ \\
\hline \multirow{4}{*}{$\begin{array}{l}\text { Parent's highest } \\
\text { educational } \\
\text { level }\end{array}$} & No qualifications & 1 & 1 \\
\hline & GCSEs & $1.14(0.71,1.82)$ & $0.83(0.52,1.32)$ \\
\hline & A-levels/diploma & $1.01(0.60,1.71)$ & $0.74(0.42,1.29)$ \\
\hline & Degree & $1.16(0.61,2.20)$ & $0.83(0.40,1.73)$ \\
\hline \multirow[t]{2}{*}{ Housing tenure } & Owner occupied & 1 & $1 * *$ \\
\hline & Rented & $1.05(0.70,1.57)$ & $1.80(1.20,2.71)$ \\
\hline
\end{tabular}

$\mathrm{OR}=$ odds ratio. Results not presented for hyperactivity at follow-up because very high collinearity with hyperactivity at baseline led to very unstable estimates. 
Table 11: Comparison of the predictors of regularly smoking and cannabis use at follow-up with lifetime smoking or cannabis use (adjusting for substance use at baseline): $\mathrm{N}=3607$

\begin{tabular}{|c|c|c|c|c|c|c|}
\hline & & & $\begin{array}{l}\text { Regular } \\
\text { smoker (OR } \\
\text { and } 95 \% \mathrm{CI}) \\
\end{array}$ & $\begin{array}{l}\text { Lifetime smoking } \\
\text { (OR and } 95 \% \mathrm{CI} \text { ) }\end{array}$ & $\begin{array}{l}\text { Regular cannabis } \\
\text { use (OR and } 95 \% \\
\text { CI) }\end{array}$ & $\begin{array}{l}\text { Lifetime cannabis } \\
\text { use (OR and } 95 \% \\
\text { CI) }\end{array}$ \\
\hline \multirow{2}{*}{$\begin{array}{l}\text { Analyses } \\
\text { using the } \\
\text { Parent SDQ }\end{array}$} & $\begin{array}{l}\text { Internalizing SDQ } \\
\text { subscale }\end{array}$ & $\begin{array}{l}\text { Change per } \\
\text { SDQ point }\end{array}$ & $0.98(0.94,1.02)$ & $0.97(0.94,1.00)$ & $0.97(0.92,1.02)$ & $0.95(0.92,0.99)^{*}$ \\
\hline & $\begin{array}{l}\text { Externalizing SDQ } \\
\text { subscale }\end{array}$ & $\begin{array}{l}\text { Change per } \\
\text { SDQ point }\end{array}$ & $\begin{array}{r}1.14(1.10, \\
1.17)^{* * *}\end{array}$ & $\begin{array}{r}1.12(1.09 \\
1.15)^{* * *}\end{array}$ & $1.08(1.03,1.13)^{* *}$ & $\begin{array}{r}1.07(1.04, \\
1.11)^{* * *}\end{array}$ \\
\hline \multirow{3}{*}{$\begin{array}{l}\text { Analyses } \\
\text { using the } \\
\text { DAWBA } \\
\text { probability } \\
\text { bands }\end{array}$} & $\begin{array}{l}\text { Internalizing } \\
\text { DAWBA band }\end{array}$ & $\begin{array}{l}\text { Change per } \\
\text { level }\end{array}$ & $1.08(0.91,1.28)$ & $1.02(0.89,1.17)$ & $1.02(0.82,1.28)$ & $1.04(0.90,1.20)$ \\
\hline & $\begin{array}{l}\text { Behavioral } \\
\text { DAWBA band }\end{array}$ & $\begin{array}{l}\text { Change per } \\
\text { level }\end{array}$ & $\begin{array}{r}1.48(1.23 \\
1.78)^{* * *}\end{array}$ & $\begin{array}{r}1.48(1.28 \\
1.72)^{* * *}\end{array}$ & $1.37(1.12,1.68)^{* *}$ & $1.30(1.12,1.49)$ \\
\hline & $\begin{array}{l}\text { Hyperactivity } \\
\text { DAWBA band }\end{array}$ & $\begin{array}{l}\text { Change per } \\
\text { level }\end{array}$ & $1.16(0.93,1.44)$ & $1.04(0.88,1.24)$ & $0.92(0.73,1.18)$ & $\begin{array}{r}0.91(0.74 \\
1.12)^{* * *} \\
\end{array}$ \\
\hline \multirow{3}{*}{$\begin{array}{l}\text { Analyses } \\
\text { using } \\
\text { clinical } \\
\text { diagnoses }\end{array}$} & $\begin{array}{l}\text { Internalizing } \\
\text { disorder }\end{array}$ & $\begin{array}{l}\text { No } \\
\text { Yes }\end{array}$ & $\begin{array}{r}1 * \\
1.65(1.08,2.52)\end{array}$ & $\begin{array}{r}1 * \\
1.50(1.02,2.19)\end{array}$ & $\begin{array}{r}1 \\
1.01(0.57,1.81)\end{array}$ & $0.99(0.65,1.50)$ \\
\hline & $\begin{array}{l}\text { Behavioral } \\
\text { disorder }\end{array}$ & $\begin{array}{l}\text { No } \\
\text { Yes } \\
\end{array}$ & $\begin{array}{r}1 * * * \\
2.83(1.72,4.64) \\
\end{array}$ & $\begin{array}{r}1 * * \\
2.29(1.43,3.66) \\
\end{array}$ & $\begin{array}{r}1 \\
1.66(0.97,2.84) \\
\end{array}$ & $\begin{array}{r}1 \\
1.52(0.97,2.38) \\
\end{array}$ \\
\hline & $\begin{array}{l}\text { Hyperactivity } \\
\text { disorder }\end{array}$ & $\begin{array}{l}\text { No } \\
\text { Yes }\end{array}$ & $1.25(0.55,2.82)$ & $\begin{array}{r}1 \\
1.51(0.68,3.35) \\
\end{array}$ & $\begin{array}{r}1 \\
0.87(0.37,2.07) \\
\end{array}$ & $0.76(0.36,1.61)$ \\
\hline
\end{tabular}

$\mathrm{OR}=$ odds ratio. All models adjust for gender; age; baseline smoking, alcohol use, cannabis use and other illicit drug use; survey year; country; ethnic group; parent education; housing tenure; family type. 
Table 12: Effect of substance use at baseline upon mental health at follow-up, with stratification by disorder presence/absence at baseline

\begin{tabular}{|c|c|c|c|c|c|}
\hline \multirow[t]{2}{*}{$\begin{array}{l}\text { Internalizing } \\
\text { disorder }\end{array}$} & & \multicolumn{4}{|l|}{$\begin{array}{l}\text { Odds ratio and } \\
95 \% \text { CI }\end{array}$} \\
\hline & & Full sample & $\begin{array}{l}\text { Internalising } \\
\text { baseline disorder } \\
\text { present (disorder } \\
\text { persistence) }\end{array}$ & $\begin{array}{l}\text { Internalising } \\
\text { baseline disorder } \\
\text { absent (incident } \\
\text { cases) }\end{array}$ & $\begin{array}{l}\text { P-value for } \\
\text { interaction with } \\
\text { baseline internalizing } \\
\text { disorder status } \\
\end{array}$ \\
\hline N cases & & 3607 & 244 & 3363 & \\
\hline Smoking & $\begin{array}{l}\text { Never } \\
\text { Ex-smoker } \\
\text { Occasional } \\
\text { Regular smoker }\end{array}$ & $\begin{array}{r}1 \\
0.88(0.43,1.79) \\
1.18(0.49,2.84) \\
0.77(0.36,1.64)\end{array}$ & $\begin{array}{r}1 \\
0.34(0.04,3.15) \\
0.43(0.09,2.14) \\
1.16(0.26,5.25)\end{array}$ & $\begin{array}{r}1 \\
0.98(0.45,2.14) \\
1.43(0.53,3.82) \\
0.74(0.30,1.87)\end{array}$ & 0.50 \\
\hline $\begin{array}{l}\text { Frequent } \\
\text { alcohol } \\
\text { consumption }\end{array}$ & $\begin{array}{l}\text { No } \\
\text { Yes }\end{array}$ & $\begin{array}{r}1 \\
1.40(0.85,2.31)\end{array}$ & $\begin{array}{r}1 \\
2.01(0.18,22.06)\end{array}$ & $1.24(0.66,2.33)$ & 0.64 \\
\hline Cannabis use & $\begin{array}{l}\text { Never } \\
\text { Less than monthly } \\
\text { Monthly or more }\end{array}$ & $\begin{array}{r}1 \\
0.75(0.30,1.92) \\
1.00(0.37,2.67)\end{array}$ & $\begin{array}{r}1 \\
0.36(0.06,2.00) \\
0.85(0.04,17.36)\end{array}$ & $\begin{array}{r}1 \\
0.78(0.25,2.40) \\
0.99(0.28,3.50)\end{array}$ & 0.62 \\
\hline $\begin{array}{l}\text { Ever used } \\
\text { other } \\
\text { illicit drug }\end{array}$ & $\begin{array}{l}\text { No } \\
\text { Yes }\end{array}$ & $\begin{array}{r}1 * \\
4.06(1.31,12.56) \\
\end{array}$ & $\begin{array}{r}1 \\
1.36(0.15,12.07) \\
\end{array}$ & $\begin{array}{r}1 * * \\
5.72(1.60,20.48) \\
\end{array}$ & 0.17 \\
\hline $\begin{array}{l}\text { Behavioral } \\
\text { disorder }\end{array}$ & & $\begin{array}{l}\text { Odds ratio and } \\
\text { 95\% CI }\end{array}$ & & & \\
\hline & & Full sample & $\begin{array}{l}\text { Externalising } \\
\text { baseline disorder } \\
\text { present (disorder } \\
\text { persistence) }\end{array}$ & $\begin{array}{l}\text { Externalising } \\
\text { baseline disorder } \\
\text { absent (incident } \\
\text { cases) }\end{array}$ & $\begin{array}{l}\text { P-value for } \\
\text { interaction with } \\
\text { baseline externalizing } \\
\text { disorder status } \\
\end{array}$ \\
\hline $\mathbf{N}$ cases & & 3607 & 235 & 3372 & \\
\hline Smoking & $\begin{array}{l}\text { Never } \\
\text { Ex-smoker } \\
\text { Occasional } \\
\text { Regular smoker }\end{array}$ & $\begin{array}{r}1 \\
1.84(0.88,3.83) \\
1.74(0.60,5.08) \\
0.83(0.32,2.14) \\
\end{array}$ & $\begin{array}{r}1 \\
1.21(0.21,6.80) \\
1.78(0.10,30.98) \\
1.15(0.28,4.67)\end{array}$ & $\begin{array}{r}1 \\
2.12(0.88,5.09) \\
1.58(0.43,5.75) \\
0.81(0.15,4.50) \\
\end{array}$ & 0.64 \\
\hline $\begin{array}{l}\text { Frequent } \\
\text { alcohol } \\
\text { consumption }\end{array}$ & $\begin{array}{l}\text { No } \\
\text { Yes }\end{array}$ & $\begin{array}{r}1 \\
1.06(0.55,2.05)\end{array}$ & $\begin{array}{r}1 \\
0.68(0.11,4.11) \\
\end{array}$ & $\begin{array}{r}1 \\
1.15(0.51,2.56) \\
\end{array}$ & 0.72 \\
\hline Cannabis use & $\begin{array}{l}\text { Never } \\
\text { Less than monthly } \\
\text { Monthly or more }\end{array}$ & $\begin{array}{r}1 \\
1.26(0.38,4.16) \\
0.65(0.17,2.52) \\
\end{array}$ & $\begin{array}{r}1 \\
0.84(0.06,11.08) \\
0.53(0.09,2.96) \\
\end{array}$ & $\begin{array}{r}1 \\
1.58(0.37,6.84) \\
0.62(0.07,5.46) \\
\end{array}$ & 0.61 \\
\hline $\begin{array}{l}\text { Ever used } \\
\text { other } \\
\text { illicit drug }\end{array}$ & $\begin{array}{l}\text { No } \\
\text { Yes }\end{array}$ & $1.31(0.26,6.65)$ & $1.24(0.13,11.83)$ & $1.99(0.20,19.62)$ & 0.36 \\
\hline
\end{tabular}

Odds ratio calculated using logistic regression. All models adjust for gender; age; baseline internalizing and externalizing mental health disorder. 